\title{
Developing Instruments to Measure Montessori Instructional Practices
}

\author{
Angela K. Murray, Carolyn J. Daoust, and Jie Chen \\ University of Kansas \\ Guest editors: Brooke Taylor Culclasure and Tracey N. Sulak
}

Keywords: Montessori education, fidelity measurement, instrument development, instructional practices

\begin{abstract}
Researchers who study any intervention must rule out potential alternative explanations for their results by establishing that the program being investigated is implemented with fidelity. Various instructional practices are attributed to the Montessori Method because the term is not legally protected, meaning any school can say it is Montessori regardless of the degree to which it adheres to practices generally understood to represent Montessori education. Researchers have used a variety of tools to measure the fidelity of Montessori environments they study, but most of these tools lack an extensive psychometric foundation or are labor intensive, requiring in-person observation. The purpose of this study was to examine the psychometric properties of instruments that were developed to measure Montessori implementation through Early Childhood (EC) and Elementary (EL) teachers' reported instructional practices. Findings supported three hypothesized dimensions of Montessori implementation (structure, curriculum, and freedom), which worked fairly well in describing practices. While the properties of these instruments are promising and provide preliminary supporting evidence, results of this analysis suggest further refinement of the items in these instruments is necessary with larger and more diverse samples. While we do not suggest that these are finalized tools, we believe they provide a valuable starting point that is a vast improvement over the requirement of investigators to develop their own instruments as part of each Montessori study they design. The authors hope other researchers will incorporate these instruments into their studies to help build a robust body of evidence supporting their use.
\end{abstract}

Since the Montessori name is not legally protected, any school can use the term regardless of the degree to which they follow the principles of the Montessori philosophy and Method (Lillard \& McHugh, 2019; MontessoriPublic, 2019). The inconsistency in what is called Montessori in schools around the world and a lack of an objective definition create confusion in public opinion as well as challenges in the field of education research (Culclasure et al., 2019). While much consensus exists within and across Montessori organizations on essential elements for authentic Montessori programs (AMI, n.d.; AMS, 2018; Culclasure Daoust, Cote, \& Zoll, 2019; MPPI, 2015), no widely accepted instrument exists for assessing the degree to 
which these environments incorporate Montessori practices. Therefore, this study's purpose was examining the suitability of instruments assessing Montessori Early Childhood (EC) and Elementary (EL) teachers' instructional practices.

\section{Review of Literature}

Fidelity evidence is crucial for demonstrating adherence to a model being investigated, allowing for consistency and replication. Without it, conclusions are limited because it is impossible to rule out confounding factors (Vartoli \& Rohs, 2009). Maria Montessori developed her Method of education more than a century ago initially to demonstrate that education of children with disabilities was possible. Today approximately 20,000 Montessori schools exist worldwide; 4,500 exist in the United States, including roughly 500 public programs (NAMTA, 2015; NCMPS, 2015). While the research base has grown along with proliferation of Montessori schools in recent years, rigorous evidence of Montessori effectiveness is limited (Marshall, 2017; Lillard et al., 2017). A consistent challenge is providing evidence of authenticity of the programs being examined due to numerous interpretations of what constitutes Montessori education (Wentworth, 1999).

\section{Fidelity Measurement}

Before discussing the issue of fidelity in the context of Montessori education, we provide an overview of the concept of fidelity measurement. In simplest terms, Century, Rudnick, and Freeman (2010) contend that "programs consist of essential features that must be measured to determine whether a program is present or not" (p. 201). In education research, fidelity measurement is a means of documenting that an intervention was implemented as planned. Researchers who are studying any intervention must examine issues of fidelity in order to establish internal validity as a means of ruling out potentially confounding factors or alternative explanations for the resulting impacts that are found (Feely, Seay, Lanier, Auslander, \& Kohl, 2017; Mowbray et al., 2003; Stains \& Vickrey, 2017). Well-developed fidelity measures can improve study power as well (Mowbray et al., 2003). Issues of fidelity can also have impacts for program administration, but that is beyond the scope of this discussion.

Mowbray and colleagues (2003) outline three steps in the process of the construction of a valid fidelity index. First, they suggest that developers must identify possible critical components of the program, which are often based on input from experts or documented explicit descriptions of the program and includes sources for each of the identified components. However, the researchers caution that:

... there is little illusion that a practical fidelity instrument can measure [the most significant program components] comprehensively. In many instances, the elements of a fidelity measure serve, in effect, as indicators of the model's design and operations-key program features that relate strongly to positive outcomes for those served - but do not necessarily include all such features, nor any features in the depth suggested by a fully explicated program theory. (p. 330)

Second, Mowbray and colleagues (2003) advise that developers collect data to measure the components, ideally using multiple data sources. Third, they indicate developers should examine the critical components in terms of their psychometric properties, including reliability and validity.

Following a process similar to Mowbray and colleagues' (2003) three steps, Feely and colleagues (2017) outline a process in their "Field Guide to Fidelity Measurement":

1. Defining purpose and scope

2. Identifying essential components

3. Developing the tool 
4. Monitoring fidelity during study

5. Using fidelity ratings in analysis

The same process is undertaken in the present study.

A common way to conceptualize the critical components of fidelity in developing a measurement tool is through considering structural components and process components. Structural components are generally considered features that relate to the framework of the intervention, while process components relate to how the intervention is implemented with respect to teachers and students (Century et al., 2010; Mowbray et al., 2003; Stains \& Vickrey, 2017).

In examining the literature regarding development of fidelity instruments, Mowbray and her team (2003) identify five approaches often used to analyze their psychometric properties; one of these is an examination of the internal structure of the empirical critical component data through approaches such as confirmatory factor analysis (CFA), cluster analysis, and/or internal consistency reliability. The use of a CFA approach in analyzing the structure of critical component empirical data is supported by other authors as well (Century et al., 2010; Stains \& Vickrey, 2017). The present study follows these recommendations through CFA as well as item response theory approaches to allow for a better understanding of the internal structure of the data gathered through the measures being piloted.

When using fidelity measures in research, some tools calculate total fidelity scores and/or incorporate specific scoring interpretation and cut-points for defining acceptable levels of overall adherence to the intervention model. Century and colleagues, however, follow a process that examines gradations of implementation accounting for a range of possible critical components, in particular combinations considering their impact on student outcomes, in order to understand the roles that particular critical components play (Century et al., 2010; Stains \& Vickrey, 2017). As a first attempt at developing a fidelity measure for Montessori education, the present study follows Century and colleagues' approach in allowing for a range of possible critical component scores without establishing ranges of acceptable performance. Such values may be developed through subsequent use of the instruments in further research studies.

In conclusion, it is important to remember that, while valid fidelity evidence is expected in research examining the effectiveness of interventions, issues of adaptation versus strict replication are also being explored in the field of education. Authors recognize that often very real situational considerations lead to the necessity or even desirability of adaptation that stand in direct contrast to the kinds of implementation purity that make for the strongest research designs (Mowbray et al., 2003; Century et al., 2010; Stains \& Vickrey, 2017). In the context of Montessori education, Dr. Mira Debs' 2019 book, Diverse Families, Desirable Schools: Public Montessori in the Era of School Choice, highlights how some efforts throughout history to preserve Montessori fidelity inadvertently limited its expansion in public programs that serve more diverse communities. She specifically references the number of teacher training programs operating independently from universities and the expense of Montessori materials as examples. Therefore, any discussion about Montessori fidelity must acknowledge potential impacts of focusing too narrowly on instructional practices without considering the larger context.

\section{Measuring Montessori Instructional Practices}

Researchers have used a variety of tools in attempts to measure the fidelity of Montessori environments they study, but most of these tools lack an extensive psychometric foundation and are labor intensive, requiring in-person observation. The instrument used in the South Carolina statewide Montessori study required trained Montessori educators to assess environments (Riley Institute for Education Policy, 2016). Lillard (2012) measured time spent with traditional Montessori materials as a gauge of authenticity. The issue of implementation fidelity is critical for Montessori education in particular because research shows that higher-fidelity programs are associated with better student outcomes (Lillard, 2012). So, a more robust and efficient method of assessing fidelity would be valuable. 
Daoust (2004) examined Montessori EC program implementation and classroom practices through a cluster analysis identifying four groups of teachers: (1) traditional following strict Montessori practice, (2) contemporary including some elements of authentic Montessori but to a lesser degree, (3) blended incorporating some traditional and Montessori practices, and (4) explorative incorporating traditional and Montessori practices but reflecting an autonomy-supporting orientation to classroom management.

Classroom practice variety is also evident in research conducted by Daoust and Suzuki (2014), who surveyed 444 public elementary Montessori teachers. Cluster analysis was used to classify the Montessori educators into meaningful groups. Post-typological analyses indicated significant differences between the identified clusters. For example, the three identified clusters differed by work period length and the extent to which children could choose their snack time. Their findings highlight an association between teacher and school characteristics and the enactment of authentic practices as useful for establishing and sustaining high-quality Montessori elementary programs in the public sector.

In summary, a high-quality, efficient fidelity instrument for Montessori education is needed and would provide the opportunity to improve the quality of future research studies on instructional practices and Montessori outcomes. The purpose of this study was to examine the suitability of items included in instruments assessing Montessori EC and EL teachers' instructional practices.

\section{Methods}

\section{Instruments}

Following the steps recommended by Mowbray and colleagues (2003), we first developed items for the Teacher Questionnaires of Montessori Practices based on extensive review of original works of Maria Montessori along with recommendations of respected Montessori organizations, writings of Montessori experts, and results from prior research examining Montessori implementation. Broad areas of focus organizing the individual items in the instruments align with inputs described in the Logic Model for Montessori Education proposed by Culclasure and colleagues (2019). Documentation of specific sources supporting the inclusion of each item in the instruments is provided in Appendices B and C. Because instructional practices differ substantially between student age groups in Montessori classrooms, 3- to 6-year-olds in EC, and 6- to 12-year-olds in EL, a separate questionnaire was developed for the EC level and the EL level, which represent the bulk of Montessori classrooms (NCMPS, 2015).

Experienced Montessori teachers and teacher educators as well as psychometricians with significant experience in instrument development provided feedback on draft versions of the Teacher Questionnaires of Montessori Practices, and earlier versions were piloted with another sample of teachers. Based on a review of pilot study results, revisions were made resulting in the instruments that were tested in this study. The revised questionnaires were reviewed by an expert panel of Montessori teacher educators, including 10 from the EC level and 13 from the EL level.

A total of 26 items rated on a 4-point Likert scale ranging from strongly disagree (1) to strongly agree (4) were included in the EC instrument, and 33 similarly rated items were included in the EL instrument. Appendix A includes the items as they were administered to participants. In addition to the items for fidelity analysis, we gathered information on professional characteristics of teachers, classroom descriptions, and teacher demographics.

\section{Procedure}

The two instruments were programmed using the Qualtrics survey platform for email distribution that contained anonymous links for potential participants. Each instrument required an average of 15 minutes to complete. Approval for this study was obtained from the University of Kansas Human Subjects Committee. 


\section{Participants}

Two groups of participants provided data for this analysis. In the first group, Montessori teachers at the EC and EL levels in an existing database maintained by Montessori Compass, an online record-keeping system, were invited to participate in the study. Survey links were emailed by the company to 6,033 subscribers and were also posted on the company's Facebook page to encourage participation. Almost half of the emails were opened $(n=2,776) ; 15$ percent of those who opened the email responded $(n=407)$. Some teachers could have been from the same school, but it is not possible to account for this possibility because of the anonymous nature of the recruitment and response.

In addition to the participants recruited from Montessori Compass, the authors posted a link in the Montessori Research Interest Facebook group to invite EC and EL teachers to participate. This Facebook group, at www.facebook.com/groups/508077912670003, is a forum for both professionals and laypeople to share research, thoughts, and opportunities; the group has more than 7,000 members.

Incorporating these additional participants and removing participants who failed to respond to any items brought the final sample to 242 for the EC data set and 170 for the EL data set. Only teachers, co-teachers, assistants, and interns from both sample sources were included in the analysis, which excluded school administrators and teachers of special subjects such as music and physical education. As outlined in Table 1, the majority of participants were lead teachers, worked in private schools, had Montessori credentials, had a median of 7 years of teaching in Montessori classrooms, and were White, non-Hispanic. Although striking, this lack of diversity and prevalence of employment in private schools are typical of a recognized issue for Montessori education (Debs, 2016). Current estimates indicate that roughly 80 percent of Montessori programs are in private schools, so the preponderance of teaching professionals from private schools in our sample is not surprising (NCMPS, 2019).

\section{Analysis}

We considered the common approach of conceptualizing the critical components of instructional practices as structural and process for our Montessori fidelity model (Century et al., 2010; Mowbray et al., 2003; Stains \& Vickrey, 2017). We decided to separate the process component into two subcomponents, curriculum and freedom, because freedom represents a fundamental aspect of Montessori education that could be conceptualized as functioning differently than other elements of Montessori practice. As a result, we hypothesized three constructs to represent the concept of Montessori fidelity based on the fidelity literature combined with previous research and a thorough review of the literature regarding Montessori philosophy and practice (Culclasure et al., 2019; Daoust, 2004; Daoust \& Suzuki, 2014). Although individual indicators differ, these three factors included classroom structure, curriculum, and children's freedom and apply both to EC and EL Montessori practice.

We provide a basic outline of our analysis procedures and results here in the main body of the article (see Figure 1); more details are available in the Technical Appendix for those who are interested. First, we used SPSS (Version 24) to conduct Pearson correlation analysis and obtained the correlation coefficients among items within each construct, comparing the results to a previous pilot study. Next, using the "lavaan" package (version 0.6-2) in R (Rosseel, 2012), we conducted confirmatory factor analysis (CFA) loading all items onto three constructs based on theory (i.e., structure, curriculum, and freedom). Factor analysis is often used in psychometric analysis of instruments providing validity evidence for hypothesized constructs (Floyd \& Widaman, 1995). The robust maximum likelihood (MLR) estimation method was used. Discussion of the reasoning behind selecting this method as well as issues of multivariate normality and missing data are provided in the Technical Appendix.

Finally, using the mirt package in R (Chalmers, 2012), we conducted unidimensional item response theory (IRT) calibration with graded response models (GRM) to estimate each item's parameters and plotted the item characteristics curve (ICC) for each of the items within each of the three constructs (see details 
Table 1

Participant Descriptions

\begin{tabular}{|c|c|c|}
\hline & $\begin{array}{c}\text { EC } \\
\%\end{array}$ & $\begin{array}{c}\text { EL } \\
\%\end{array}$ \\
\hline Total & $N=242$ & $N=170$ \\
\hline \multicolumn{3}{|l|}{ Role in classroom (multi-response) } \\
\hline -Lead teacher & 79 & 72 \\
\hline -Co-teacher & 15 & 13 \\
\hline -Assistant & 10 & 3 \\
\hline -Intern & 3 & 1 \\
\hline \multicolumn{3}{|l|}{ Type of school } \\
\hline -Private & 80 & 67 \\
\hline -Public & 20 & 33 \\
\hline \multicolumn{3}{|l|}{ Montessori credential } \\
\hline -Yes & 82 & 76 \\
\hline -No & 5 & 6 \\
\hline -In progress & 11 & 12 \\
\hline -At another level & 3 & 6 \\
\hline \multicolumn{3}{|l|}{ Race (multi-response) } \\
\hline -American Indian or Alaska Native & 2 & 1 \\
\hline -Asian & 8 & 5 \\
\hline -Black or African American & 6 & 3 \\
\hline -Native Hawaiian or Other Pacific Islander & $<1$ & 1 \\
\hline -White & 78 & 88 \\
\hline -Prefer not to answer & 8 & 7 \\
\hline Hispanic ethnicity & 8 & 6 \\
\hline Female & 95 & 90 \\
\hline \multicolumn{3}{|l|}{ Years Montessori teaching } \\
\hline -Mean & 10.57 & 10.42 \\
\hline$-\mathrm{SD}$ & 9.19 & 8.09 \\
\hline -Median & 7 & 7 \\
\hline
\end{tabular}

in Technical Appendix). These items have no single correct answer, so we used IRT to describe the data with the rating scale measuring degrees of agreement with Montessori instructional practices. We estimated b-parameters (i.e., item difficulty) and a-values (i.e., item discrimination) because IRT is based on the concept that it is possible to separate a person's responses to items from their underlying performance on the latent construct the scale is measuring (Hambleton, Swaminathan, \& Rogers, 1991). In this case, ability would represent a teacher's degree of Montessori fidelity. For the purposes of the IRT analysis, we collapsed all responses of 1 and 2 because there were two items for which no participants responded with 1 , and across almost all items the proportion of 1 responses was very small. 


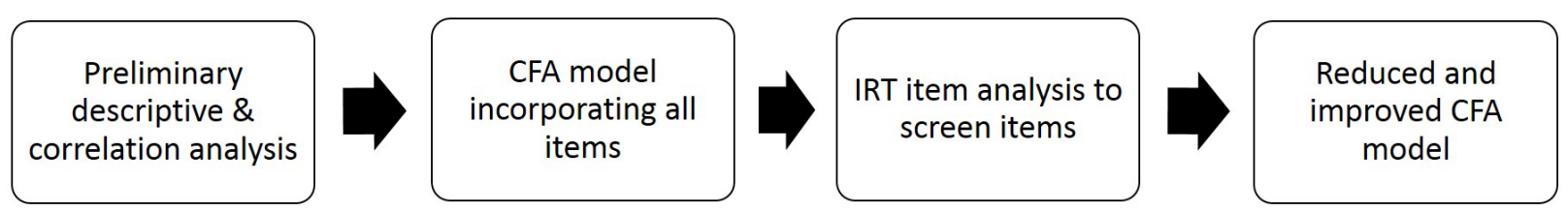

Figure 1. Analysis process for development of instruments.

\section{Results}

Descriptive results from all items initially examined are provided in Table 2 for EC and Table 3 for EL where stronger levels of agreement would be expected to reflect higher-fidelity Montessori practice. As mentioned previously, agreement tends to be skewed toward the positive end of the scale for most items. Further analysis of the univariate skewness and kurtosis of these items is provided in the Technical Appendix.

Initial CFA model results incorporating all items suggested promise with all but two of the paths significant, but model fit statistics indicated improvement was possible with details provided in the Technical Appendix. Therefore, we used IRT to identify items that could be removed from the scale to improve the instruments.

Based on results of IRT analysis, we dropped items with an inversed ICC (i.e., lower ability has a higher probability of agreement) or a flat ICC (i.e., suggesting that items do not discriminate among participants). Table 4 shows the number of items before and after eliminating items from each data set. Although with 242 EC and 170 EL participants, sample sizes for these two groups are smaller than typically recommended for these analyses, the models converged and results suggest relatively strong model fit, particularly in the improved model, as evident in the Technical Appendix (Lewis, 2017).

IRT analysis produced item parameters shown in Tables 5 and 6 with model fit statistics available in the Technical Appendix. The b-mean parameters for the retained items range from -0.025 to -2.55 , and the a-parameters range from 0.63 to 4.22 . We can say that the larger the b-mean is, the more people selected the lower ends of the scale representing lower fidelity; the smaller the b-mean is, the more people selected the higher ends of the scale representing higher fidelity. By looking at the b-mean value, we can tell if more people agree or disagree on the statement. A larger a-value indicates the item is more discriminant, meaning the responses are more spread to distinguish different degrees of Montessori practices. A smaller a-value indicates the opposite (Edelen \& Reeve, 2007).

After deleting problematic items, we ran a CFA analysis on the reduced set of items for both EC and EL. While the benefit of using a CFA approach is the ability to quantify model fit, there is not one generally accepted measure to evaluate the results. Instead, it is suggested that multiple fit indices be used (Thompson, 2004). We examined the most commonly reported indices: (a) chi-square $\left(X^{2}\right)$, (b) comparative fit index (CFI), and (c) root mean square error of approximation (RMSEA). Results from the initial CFA with all items included are provided in Table 7 along with the improved model fit statistics for comparison purposes.

A statistically significant chi square indicates that the model is not effectively reproducing the observed patterns of relationships. Our final CFA results showed a nonsignificant chi square at an alpha level of .05 for the EC sample but a significant chi square for the EL sample. However, our CFI values for the EC and EL improved models were both above .90 , indicating excellent fit, and we found RMSEA values well below .08, which is considered indicative of an adequate model (Browne \& Cudeck, 1993). The Technical Appendix contains details regarding the factor loadings both before and after items were removed from the analysis. Therefore, we conclude that the models for each age level with three latent factors fit the data to an acceptable degree. Although the model fit for the three-construct CFA model outperformed that of the 
Table 2

Response Proportion on EC Items by Construct (some items shortened for space)

\begin{tabular}{|c|c|c|c|c|c|c|}
\hline Item \# & Item & 1 & 2 & 3 & 4 & Missing \\
\hline \multicolumn{7}{|c|}{ Structure } \\
\hline Q4_02 & At least 3 age levels. & 0.07 & 0.04 & 0.06 & 0.83 & 0.00 \\
\hline Q4_06 & Children give lessons to one another. & 0.05 & 0.06 & 0.38 & 0.51 & 0.00 \\
\hline Q4_08 & At least 25 children typically attend each day. & 0.35 & 0.14 & 0.17 & 0.34 & 0.00 \\
\hline Q6_01 & Observation is used for daily lesson planning. & 0.03 & 0.05 & 0.32 & 0.59 & 0.01 \\
\hline Q6_02 & Children's activities are recorded each day. & 0.05 & 0.09 & 0.31 & 0.54 & 0.00 \\
\hline Q6_03 & There is a 3-hour uninterrupted work period. & 0.07 & 0.16 & 0.35 & 0.42 & 0.01 \\
\hline Q6_04 & Lessons are mostly given to individuals. & 0.03 & 0.12 & 0.35 & 0.50 & 0.00 \\
\hline Q7_07 & Are evenly spread across at least a 3-yr age span. & 0.10 & 0.14 & 0.26 & 0.49 & 0.00 \\
\hline \multicolumn{7}{|c|}{ Curriculum } \\
\hline Q4_01 & A full set of Montessori materials is available. & 0.02 & 0.05 & 0.16 & 0.76 & 0.00 \\
\hline Q4_05 & Art materials are available all day. & 0.02 & 0.05 & 0.15 & 0.78 & 0.00 \\
\hline Q4_07 & A polishing activity is available. & 0.08 & 0.06 & 0.20 & 0.65 & 0.00 \\
\hline Q6_05 & Breakable materials are available. & 0.01 & 0.03 & 0.08 & 0.87 & 0.01 \\
\hline Q6_06 & Classroom books feature realistic stories. & 0.02 & 0.07 & 0.35 & 0.56 & 0.00 \\
\hline Q6_07 & Children regularly prepare food. & 0.10 & 0.16 & 0.29 & 0.45 & 0.00 \\
\hline Q6_08 & Older children do golden bead addition. & 0.07 & 0.06 & 0.19 & 0.67 & 0.01 \\
\hline Q7_03 & Care for classroom plants. & 0.05 & 0.04 & 0.22 & 0.69 & 0.00 \\
\hline Q7_04 & Care for classroom animals. & 0.20 & 0.11 & 0.20 & 0.47 & 0.02 \\
\hline Q7_08 & Walk on the line carrying objects. & 0.11 & 0.11 & 0.28 & 0.50 & 0.01 \\
\hline Q7_09 & Regularly use the Montessori bells. & 0.41 & 0.17 & 0.22 & 0.18 & 0.01 \\
\hline Q7_10 & Garden is in a designated area. & 0.15 & 0.10 & 0.26 & 0.48 & 0.01 \\
\hline \multicolumn{7}{|c|}{ Freedom } \\
\hline Q4_03 & Children may choose to skip circle time. & 0.14 & 0.21 & 0.39 & 0.26 & 0.00 \\
\hline Q4_04 & Snack is a self-serve activity. & 0.06 & 0.05 & 0.10 & 0.79 & 0.00 \\
\hline Q7_01 & May choose to work alone or with others. & 0.00 & 0.04 & 0.22 & 0.73 & 0.01 \\
\hline Q7_02 & Decide where they will work. & 0.00 & 0.03 & 0.21 & 0.75 & 0.02 \\
\hline Q7_05 & Choose their work/activities. & 0.00 & 0.02 & 0.23 & 0.74 & 0.01 \\
\hline Q7_06 & Determine how long to work with an activity. & 0.01 & 0.02 & 0.24 & 0.72 & 0.01 \\
\hline
\end{tabular}

Note: All items were included.

one dimension of Montessori fidelity, model fit was improved when the factors were allowed to correlate, as shown in Table 8. More details about the CFA analysis, including the significance of the paths, are provided in the Technical Appendix.

Finally, internal consistency of the refined total scales and their respective subscales was measured using Cronbach's alpha. Cronbach's alpha is commonly reported for studies of instrument validity because it provides information about the degree to which all the items in a scale measure the same construct. Simply stated, Cronbach's alpha has a range of possible values between 0 and 1 and can be thought of as the correlation of a scale with itself. The total EC scale with 18 items had a coefficient alpha of .82 with the 6 struc- 
Table 3

Response Proportion on EL Items by Construct (some items shortened for space)

\begin{tabular}{|c|c|c|c|c|c|c|}
\hline Item \# & Item & 1 & 2 & 3 & 4 & Missing \\
\hline \multicolumn{7}{|c|}{ Structure } \\
\hline Q4_01 & Children are in at least 3 grade levels. & 0.06 & 0.02 & 0.05 & 0.87 & 0.00 \\
\hline Q4_03 & All children go out for lunchtime recess. & 0.05 & 0.02 & 0.15 & 0.77 & 0.01 \\
\hline Q4_06 & Most lessons last 15 minutes or less. & 0.05 & 0.12 & 0.46 & 0.36 & 0.00 \\
\hline Q4_07 & Problem-solving for off-task behavior. & 0.02 & 0.06 & 0.34 & 0.58 & 0.01 \\
\hline Q4_08 & 1 -on- 1 meetings at least every 2 weeks. & 0.09 & 0.18 & 0.32 & 0.40 & 0.00 \\
\hline Q6_02 & Observation used for daily lesson planning. & 0.01 & 0.06 & 0.42 & 0.50 & 0.01 \\
\hline Q6_05 & Children record activities in work journals. & 0.05 & 0.08 & 0.15 & 0.71 & 0.01 \\
\hline Q6_06 & There is a 3-hour uninterrupted work period. & 0.05 & 0.06 & 0.26 & 0.63 & 0.01 \\
\hline Q6_07 & Children give lessons to one another. & 0.01 & 0.08 & 0.48 & 0.42 & 0.01 \\
\hline Q6_08 & Most lessons given in groups of 2-5. & 0.03 & 0.09 & 0.38 & 0.49 & 0.01 \\
\hline \multicolumn{7}{|c|}{ Curriculum } \\
\hline Q4_04 & Spelling exercises are individualized. & 0.05 & 0.05 & 0.41 & 0.47 & 0.01 \\
\hline Q4_10 & Art materials are available all day. & 0.05 & 0.11 & 0.24 & 0.60 & 0.00 \\
\hline Q4_11 & Children correct their own work. & 0.02 & 0.12 & 0.54 & 0.32 & 0.01 \\
\hline Q4_12 & Full set of large geography charts. & 0.11 & 0.09 & 0.24 & 0.56 & 0.00 \\
\hline Q6_01 & Great Lessons/Stories are given each fall. & 0.05 & 0.07 & 0.23 & 0.64 & 0.01 \\
\hline Q6_03 & Use human fundamental needs charts. & 0.07 & 0.12 & 0.37 & 0.43 & 0.01 \\
\hline Q6_09 & Most instruction with Montessori materials. & 0.02 & 0.04 & 0.24 & 0.69 & 0.01 \\
\hline Q6_10 & Children regularly prepare food. & 0.17 & 0.21 & 0.26 & 0.36 & 0.01 \\
\hline Q7_07 & Make history timelines. & 0.06 & 0.17 & 0.39 & 0.36 & 0.01 \\
\hline Q7_08 & Create their own math problems. & 0.08 & 0.28 & 0.41 & 0.22 & 0.01 \\
\hline Q7_09 & Repeat Montessori science experiments. & 0.04 & 0.21 & 0.34 & 0.40 & 0.01 \\
\hline Q7_10 & Have access to full set of Montessori materials. & 0.02 & 0.02 & 0.21 & 0.74 & 0.01 \\
\hline Q7_11 & Take part in community service projects. & 0.04 & 0.14 & 0.42 & 0.39 & 0.01 \\
\hline \multicolumn{7}{|c|}{ Freedom } \\
\hline Q4_02 & Children decide when to have snack. & 0.06 & 0.08 & 0.14 & 0.72 & 0.00 \\
\hline Q4_05 & Small groups do "going out" excursions. & 0.24 & 0.18 & 0.24 & 0.33 & 0.02 \\
\hline Q4_09 & Children make classroom rules/guidelines. & 0.03 & 0.02 & 0.19 & 0.76 & 0.00 \\
\hline Q6_04 & Children create room maintenance system. & 0.02 & 0.06 & 0.40 & 0.51 & 0.01 \\
\hline Q7_01 & Do research based on interests. & 0.01 & 0.03 & 0.35 & 0.61 & 0.01 \\
\hline Q7_02 & Choose their work/activities. & 0.01 & 0.02 & 0.41 & 0.54 & 0.02 \\
\hline Q7_03 & Decide if they will do a follow-up activity. & 0.06 & 0.21 & 0.48 & 0.24 & 0.01 \\
\hline Q7_04 & Determine how long to work with activity. & 0.01 & 0.04 & 0.39 & 0.55 & 0.02 \\
\hline Q7_05 & Decide where they will work. & 0.01 & 0.04 & 0.27 & 0.67 & 0.01 \\
\hline Q7_06 & May choose to work alone or with others. & 0.01 & 0.02 & 0.18 & 0.78 & 0.01 \\
\hline
\end{tabular}

Note: All items included. 
Table 4

Number of Items by Construct

\begin{tabular}{lccccc}
\hline \multirow{2}{*}{ Construct } & \multicolumn{2}{c}{ EC } & & \multicolumn{2}{c}{ EL } \\
\cline { 2 - 3 } \cline { 5 - 6 } & $\begin{array}{c}\text { Original number of } \\
\text { items }\end{array}$ & $\begin{array}{c}\text { Final number } \\
\text { of items }\end{array}$ & & $\begin{array}{c}\text { Original number of } \\
\text { items }\end{array}$ & $\begin{array}{c}\text { Final number of } \\
\text { items }\end{array}$ \\
\hline Structure & 8 & 6 & & 10 & 7 \\
Curriculum & 12 & 8 & & 12 & 9 \\
Freedom & 6 & 4 & & 11 & 6 \\
Total items & 26 & 18 & & 33 & 22 \\
\hline
\end{tabular}

ture items at .62, 8 curriculum items at .75, and 4 freedom items at .80. The total EL scale of 22 items had a coefficient alpha of .88 with the 7 structure items at $.69,9$ curriculum items at .80 , and 6 freedom items at .68. Acceptable values of alpha range from .70 to .95 . Cronbach's alpha of the total scale for both EC and EL is fairly high, and most subscales approach the acceptable range. The lowest value of Cronbach's alpha is from the structure subscale for EC at .62. The values of alpha for subscales are understandably lower than that for the total scale because there are fewer items in each of the subscales (Tavakol \& Dennick, 2011).

Table 5

EC Item Parameters by Construct

\begin{tabular}{lcrrr}
\hline Item \# & a & b1 & b2 & b-mean \\
\hline Factor 1. Structure & & & & \\
\hline Q4_01 & 0.72 & -3.07 & -0.21 & -1.64 \\
Q6_01 & 1.40 & -2.39 & -0.47 & -1.43 \\
Q6_02 & 1.16 & -2.12 & -0.26 & -1.19 \\
Q6_03 & 0.85 & -1.78 & 0.38 & -0.70 \\
Q6_04 & 1.01 & -2.25 & -0.10 & -1.17 \\
Q7_07 & 1.10 & -1.27 & 0.07 & -0.60 \\
\hline Factor 2. Curriculum & & & & \\
\hline Q4_01 & 1.10 & -3.03 & -1.37 & -2.20 \\
Q4_07 & 1.44 & -1.71 & -0.63 & -1.17 \\
Q6_06 & 0.63 & -4.54 & -0.56 & -2.55 \\
Q6_07 & 1.29 & -1.12 & 0.14 & -0.49 \\
Q6_08 & 1.19 & -2.04 & -0.83 & -1.43 \\
Q7_03 & 1.44 & --2.33 & -0.89 & -1.61 \\
Q7_08 & 1.46 & -1.40 & -0.12 & -0.76 \\
Q7_10 & 0.88 & -1.52 & 0.02 & -0.75 \\
\hline Factor 3. Freedom & & & & \\
\hline Q7_01 & 1.37 & -3.07 & -1.03 & -2.05 \\
Q7_02 & 2.07 & -2.74 & -0.93 & -1.84 \\
Q7_05 & 4.22 & -2.25 & -0.71 & -1.48 \\
Q7_06 & 1.41 & -3.15 & -0.94 & -2.05 \\
\hline
\end{tabular}


Table 6

EL Item Parameters by Construct

\begin{tabular}{lcrrr}
\hline Item \# & a & b1 & b2 & b-mean \\
\hline Factor 1. Structure & & & & \\
\hline Q4_07 & 0.79 & -3.47 & -0.48 & -1.974 \\
Q4_08 & 0.92 & -1.23 & 0.53 & -0.350 \\
Q6_02 & 1.37 & -2.40 & 0.01 & -1.193 \\
Q6_05 & 0.66 & -3.08 & -1.51 & -2.294 \\
Q6_06 & 1.50 & -1.88 & -0.46 & -1.171 \\
Q6_07 & 0.92 & -2.76 & 0.43 & -1.164 \\
Q6_08 & 1.68 & -1.65 & 0.03 & -0.811 \\
\hline Factor 2. Curriculum & & & & \\
\hline Q4_11 & 0.83 & -2.43 & 1.06 & -0.688 \\
Q6_01 & 1.08 & -2.17 & -0.69 & -1.433 \\
Q6_03 & 2.07 & -1.12 & 0.21 & -0.458 \\
Q6_09 & 1.25 & -2.69 & -0.85 & -1.773 \\
Q6_10 & 1.20 & -0.52 & 0.62 & 0.047 \\
Q7_07 & 1.73 & -0.98 & 0.48 & -0.251 \\
Q7_09 & 1.89 & -0.90 & 0.32 & -0.291 \\
Q7_10 & 1.71 & -2.59 & -0.94 & -1.765 \\
Q7_11 & 1.26 & -1.54 & 0.42 & -0.560 \\
\hline Factor 3. Freedom & & & & -1.42 \\
\hline Q4_02 & 0.71 & -2.68 & -1.42 & -2.05 \\
Q4_09 & 1.59 & -2.43 & -1.04 & -1.73 \\
Q7_01 & 1.12 & -3.44 & -0.53 & -1.98 \\
Q7_02 & 1.61 & -2.84 & -0.20 & -1.52 \\
Q7_04 & 1.82 & -2.30 & -0.18 & -1.24 \\
Q7_05 & 1.75 & -2.37 & -0.65 & -1.51 \\
\hline & & & & \\
\hline
\end{tabular}

\section{Discussion}

Results suggest that three hypothesized dimensions of Montessori fidelity (structure, curriculum, and freedom) work well in describing EC and EL practices. Furthermore, items in the final analysis did a reasonable job of reflecting the performance of this sample of Montessori teachers on these dimensions. However, further study is necessary before recommending use of these instruments as vetted tools for widespread use in research projects. While promising, results suggest that further refinement of items in these fidelity instruments with larger and more diverse samples is necessary.

Limitations of this study include small sample sizes and relatively homogeneous samples of Montessori teachers, which could introduce bias, so it will be important to expand future applications of these instruments to strengthen the evidence for its use in a variety of contexts and with larger and more representative samples. Specifically, since our models were modified post hoc based on this particular sample, sampling bias could limit the replicability of these results. Furthermore, these instruments are based on 
Table 7

CFA Model Fit Comparison: Initial Model vs. Improved Model

\begin{tabular}{llcrcccc}
\hline \multicolumn{1}{c}{ Data } & \multicolumn{1}{c}{ Model } & $\boldsymbol{\chi}^{\mathbf{2}}$ & $\mathbf{d f}$ & $\boldsymbol{p}$ & RMSEA & RMSEA 90\% CI & CFI \\
\hline EC & Initial & 266.63 & 192 & $<.001$ & .04 & $.028-.051$ & .934 \\
& Improved & 100.62 & 83 & .09 & .03 & $.000-.047$ & .972 \\
\hline \multirow{2}{*}{ EL } & Initial & 459.14 & 324 & $<.001$ & .05 & $.039-.059$ & .889 \\
& Improved & 172.69 & 134 & .01 & .04 & $.021-.057$ & .947 \\
\hline
\end{tabular}

teacher self-report, which will require further research to confirm alignment with actual observed practices. Next steps in investigating the validity of these fidelity measurement tools for research purposes involve incorporating the scales into studies of other aspects of Montessori education to investigate relationships with these constructs as well as outcome measures while understanding that additional evidence to support the appropriateness of using this tool is necessary at this point in its development.

Table 8

Covariance Between Latent Variables in the Improved CFA Model for EC and EL Data

\begin{tabular}{llcccccc}
\hline & & EC & & \multicolumn{3}{c}{ EL } \\
\cline { 2 - 3 } \cline { 6 - 8 } Constructs & $\mathbf{1}$ & $\mathbf{2}$ & $\mathbf{3}$ & & $\mathbf{1}$ & $\mathbf{2}$ & $\mathbf{3}$ \\
\hline 1. Structure & - & & & & - & & \\
2. Curriculum & .72 & - & & & .70 & - & \\
3. Freedom & .38 & $.35^{* * *}$ & - & & $.60^{* * *}$ & .66 & - \\
\hline
\end{tabular}

$* * * p<.001$.

To facilitate the use of the Teacher Questionnaires of Montessori Practices, we encourage other researchers to contact us about using these instruments in their work and to help us continue to build a dataset for examining their psychometric properties.

\section{AUTHOR INFORMATION}

\section{$\dagger$ Corresponding Author}

Angela Murray $\uparrow$ is the director of the University of Kansas Center for Montessori Research and can be reached at akmurray@ku.edu.

Carolyn Daoust is a research associate at the University of Kansas Center for Montessori Research.

Jie Chen is a Psychometrician and research associate at the University of Kansas Center for Montessori Research.

\section{References}

American Montessori Society (AMS). (2018). AMS Accreditation Standards. Retrieved from https://amshq.org/Educators/Montessori-Schools/AMS-Accreditation/Accreditation-Standards

Association of Montessori International/USA. (AMI/USA). (n.d.). AMI/USA School Standards. Retrieved from https://amiusa.org/school-standards 
Browne, M. W., \& Cudeck, R. (1993). Alternate ways of assessing model fit. In K. A. Bollen \& J. S. Long (Eds.), Testing structural equation models (pp.136-162). Newbury Park, CA: Sage. doi:10.1177/0049124192021002005

Century, J., Rudnick, M., \& Freeman, C. (2010). A Framework for measuring fidelity of implementation: A foundation for shared language and accumulation of knowledge. American Journal of Evaluation, 31(2) 199-218. doi:0.1177/1098214010366173

Chalmers, R. P. (2012). mirt: A Multidimensional Item Response Theory Package for the R Environment. Journal of Statistical Software, 48(6), 1-29. doi:10.18637/jss.v048.i06

Culclasure, B., Daoust, C., Cote, S., \& Zoll, S. (2019). A logic model for Montessori education. Journal of Montessori Research, 5(1).

Daoust, C. J. (2004). An examination of implementation practices in Montessori Early Childhood education (unpublished doctoral dissertation). St. Mary's College, Moraga, CA.

Daoust, C., \& Suzuki, S. (2014). Public Montessori Elementary: Three models of implementation. Poster presented at the AMS 2014 Annual Conference in Dallas, TX.

Debs, M. (2016). Racial and economic diversity in U.S. public Montessori schools. Journal of Montessori Research, 2(2), 15-34. Retrieved from https://journals.ku.edu/jmr/article/view/5848/5884. Accessed 22 July 2018. doi:10.17161/jomr.v2i2.5848

Debs, M. (2019). Diverse Families, Desirable Schools: Public Montessori in the Era of School Choice. Cambridge, MA: Harvard Education Press.

Edelen, M. O., \& Reeve, B. B. (2007). Applying item response theory (IRT) modeling to questionnaire development, evaluation, and refinement. Quality of Life Research, 16:5-18. doi:10.1007/s11136-0079198-0

Feely, M., Seay, K., Lanier, P., Auslander, W., \& Kohl, P. (2017). Measuring fidelity in research studies: A field guide to developing a comprehensive fidelity measurement system. Child and Adolescent Social Work Journal. doi:10.1007/s10560-017-0512-6

Floyd, F. J., \& Widaman, K. F. (1995). Factor analysis in the development and refinement of clinical assessment instruments. Psychological Assessment, 7, 286-299. doi:10.1037/1040-3590.7.3.286

Hambleton, R. K., Swaminathan, H., \& Rogers, H. J. (1991). Fundamentals of Item Response Theory. Newbury Park, CA: Sage.

Lillard, A. S. (2012). Preschool children's development in classic Montessori, supplemented Montessori, and conventional programs. Journal of School Psychology, 50, 379-401. doi:10.1016/j.jsp.2012.01.001

Lillard, A. S., Heise, M. J., Richey, E. M., Tong, X., Hart, A., \& Bray, P. M. (2017). Montessori preschool elevates and equalizes child outcomes: A longitudinal study. Frontiers in Psychology, 8, 1783. doi:10.3389/fpsyg.2017.01783

Lillard, A., \& McHugh, V. (2019). Authentic Montessori: Part I: The environment: The Dottoressa's view at the end of her life. Journal of Montessori Research, 5(1).

Marshall, C. (2017). Montessori education: A review of the evidence base. npj Science of Learning, 11. doi:10.1038/s41539-017-0012-7

Montessori Public Policy Initiative (MPPI). (2015). Montessori essentials. Retrieved October 10, 2016, from https://www.montessoriadvocacy.org/resources

MontessoriPublic. (2019, March 3). Montessori education. National Center for Montessori in the Public Sector. Retrieved from https://www.montessoripublic.org/montessori/montessori-education 
National Center for Montessori in the Public Sector (NCMPS). (2015, February 6). Growth of public Montessori in the United States: 1975-2014. Retrieved from http://www.public-montessori.org/growth-public-montessori-united-states-1975-2014

National Center for Montessori in the Public Sector (NCMPS). (2019, March 3). NCMPS rubric of essential elements of Montessori practice in the public sector. Retrieved from https://www.public-montessori. org/resources/launching-a-public-montessori-school/ncmps-rubric-of-essential-elements-of-montessori-practice-in-the-public-sector

North American Montessori Teacher Association (NAMTA). (2015, February 6). How many Montessori schools are there? Retrieved from http://www.montessori-namta.org/FAQ/Montessori-Education/Howmany-Montessori-schools-are-there

Riley Institute for Education Policy. (2016). The S.C. public Montessori study: Classroom observation data. Retrieved from https://riley.furman.edu/sites/default/files/docs/ClassroomObservationSummariesYR ONE_TWO_THREE_FOUR.pdf

Lewis, T. F. (2017). Evidence regarding the internal structure: Confirmatory factor analysis. Measurement and Evaluation in Counseling and Development, 50(4), 239-247. doi:10.1080/07481756.2017.1336929

Mowbray, C., Holter, M., Teague, G., \& Bybree, D. (2003). Fidelity criteria: Development, measurement, and validation. American Journal of Education, 24(3). doi:10.1177/109821400302400303

Rosseel, Y. (2012). Lavaan: An R package for structural equation modeling. Journal of Statistical Software, 48(2), 1-36. Retrieved from http://www.jstatsoft.org/v48/i02

Stains, M., \& Vickrey, T. (2017). Fidelity of implementation: An overlooked yet critical construct to establish effectiveness of evidence-based instructional practices. CBE Life Sciences Education. doi:10.1187/ cbe.16-03-0113

Tavakol, M., \& Dennick, R. (2011). Making sense of Cronbach's alpha. International Journal of Medical Education, 2:53-55. Retrieved from https://www.ijme.net/archive/2/cronbachs-alpha.pdf doi:10.5116/ ijme. $4 \mathrm{dfb} .8 \mathrm{dfd}$

Thompson, B. (2004). Exploratory and confirmatory factor analysis: Understanding concepts and applications. Washington, DC: American Psychological Association.

Vartoli, S., \& Rohs, J. (2009). Assurance of outcome evaluation: Curriculum fidelity. Journal of Research in Childhood Education, 23(4), 502.

Wentworth, R. L. (1999). Montessori for the new millennium. Mahwah, NJ: Erlbaum. 


\section{Appendix A}

\section{Instruments}

Early Childhood

Q4 Please indicate how strongly you agree or disagree with each of the following statements about your classroom. In my classroom...

\begin{tabular}{lcccc} 
& $\begin{array}{c}\text { Strongly } \\
\text { disagree }\end{array}$ & $\begin{array}{c}\text { Somewhat } \\
\text { disagree }\end{array}$ & $\begin{array}{c}\text { Somewhat } \\
\text { agree }\end{array}$ & $\begin{array}{c}\text { Strongly } \\
\text { agree }\end{array}$ \\
\hline A full set of Montessori materials is available. & 0 & 0 & 0 & 0 \\
There are at least 3 age levels. & 0 & 0 & 0 & 0 \\
Children may choose to skip circle time. & 0 & 0 & 0 & 0 \\
Snack is a self-serve activity. & $\circ$ & 0 & 0 & 0 \\
Art materials are available all day. & 0 & 0 & 0 & 0 \\
Children give lessons to one another. & $\circ$ & 0 & 0 & 0 \\
A polishing activity is available. & 0 & 0 & 0 & 0 \\
At least 25 children typically attend each day. & $\circ$ & 0 & 0 & 0 \\
\hline
\end{tabular}

Q6 Please indicate how strongly you agree or disagree with each of the following statements about your classroom. I make sure that...

\begin{tabular}{|c|c|c|c|c|}
\hline & $\begin{array}{l}\text { Strongly } \\
\text { disagree }\end{array}$ & $\begin{array}{c}\text { Somewhat } \\
\text { disagree }\end{array}$ & $\begin{array}{l}\text { Somewhat } \\
\text { agree }\end{array}$ & $\begin{array}{c}\text { Strongly } \\
\text { agree }\end{array}$ \\
\hline Observation is used for daily lesson planning. & o & o & o & o \\
\hline Children's activities are recorded each day. & ○ & ○ & o & o \\
\hline There is a 3-hour uninterrupted work period. & o & o & o & o \\
\hline Lessons are mostly given to individuals. & o & o & o & o \\
\hline Breakable materials are available. & 0 & 0 & 0 & 0 \\
\hline Classroom books feature realistic stories. & o & o & o & o \\
\hline Children regularly prepare food. & o & 0 & o & o \\
\hline Older children do golden bead addition. & o & 0 & 0 & 0 \\
\hline
\end{tabular}


Q7 Please indicate how strongly you agree or disagree with each of the following statements about your classroom. The children in my classroom...

\begin{tabular}{|c|c|c|c|c|}
\hline & $\begin{array}{l}\text { Strongly } \\
\text { disagree }\end{array}$ & $\begin{array}{c}\text { Somewhat } \\
\text { disagree }\end{array}$ & $\begin{array}{c}\text { Somewhat } \\
\text { agree }\end{array}$ & $\begin{array}{c}\text { Strongly } \\
\text { agree }\end{array}$ \\
\hline May choose to work alone or with others. & 0 & 0 & ० & o \\
\hline Decide where they will work. & ○ & ○ & ○ & $\circ$ \\
\hline Care for classroom plants. & ० & ○ & ○ & $\circ$ \\
\hline Care for classroom animals. & o & ○ & ○ & $\circ$ \\
\hline Choose their work/activities. & 0 & 0 & ० & ० \\
\hline Determine how long to work with an activity. & ○ & ○ & ○ & $\circ$ \\
\hline Are evenly spread across at least a 3 -yr age span. & $\circ$ & 0 & ० & ○ \\
\hline Walk on the line carrying objects. & ○ & ○ & ○ & $\circ$ \\
\hline Regularly use the Montessori bells. & 0 & ○ & ० & ० \\
\hline Garden in a designated area. & $\circ$ & ○ & $\circ$ & $\circ$ \\
\hline
\end{tabular}

Elementary

Q4 Please indicate how strongly you agree or disagree with each of the following statements about your classroom. In my classroom...

\begin{tabular}{|c|c|c|c|c|}
\hline & $\begin{array}{l}\text { Strongly } \\
\text { disagree }\end{array}$ & $\begin{array}{c}\text { Somewhat } \\
\text { disagree }\end{array}$ & $\begin{array}{l}\text { Somewhat } \\
\text { agree }\end{array}$ & $\begin{array}{c}\text { Strongly } \\
\text { agree }\end{array}$ \\
\hline Children are in at least 3 grade levels. & o & o & o & o \\
\hline Children decide when to have snack. & o & o & o & o \\
\hline All children go out for lunchtime recess. & o & 0 & 0 & 0 \\
\hline Spelling exercises are individualized. & o & o & o & o \\
\hline Small groups do "going out" excursions. & o & o & o & o \\
\hline Most lessons last 15 minutes or less. & o & o & o & o \\
\hline Problem solving with students addresses off-task behavior. & 0 & o & o & 0 \\
\hline 1 -on-1 meetings are held at least every 2 weeks. & o & ○ & o & o \\
\hline Children help make classroom rules/guidelines. & o & o & o & o \\
\hline Art materials are available all day. & o & o & o & o \\
\hline Children correct their own work. & o & 0 & 0 & 0 \\
\hline There is a full set of large geography charts. & o & o & o & 0 \\
\hline
\end{tabular}


Q6 Please indicate how strongly you agree or disagree with each of the following statements about your classroom. I make sure that...

\begin{tabular}{lcccc} 
& $\begin{array}{c}\text { Strongly } \\
\text { disagree }\end{array}$ & $\begin{array}{c}\text { Somewhat } \\
\text { disagree }\end{array}$ & $\begin{array}{c}\text { Somewhat } \\
\text { agree }\end{array}$ & $\begin{array}{c}\text { Strongly } \\
\text { agree }\end{array}$ \\
\hline Montessori Great Lessons/Stories are given each fall. & 0 & 0 & 0 & 0 \\
Observation is used for daily lesson planning. & 0 & 0 & 0 & 0 \\
Children use human fundamental needs charts. & 0 & 0 & 0 & 0 \\
Children develop a system for classroom maintenance. & 0 & 0 & $\circ$ & 0 \\
Children record activities in work journals. & 0 & 0 & $\circ$ & 0 \\
There is a 3-hour uninterrupted work period. & 0 & 0 & 0 & 0 \\
Children give lessons to one another. & 0 & 0 & 0 & 0 \\
Most lessons are given in groups of 2-5 children. & 0 & 0 & 0 & 0 \\
Most instruction is given with Montessori materials. & 0 & 0 & 0 & 0 \\
Children regularly prepare food. & $\circ$ & 0 & 0 & $\circ$ \\
\hline
\end{tabular}

Q7 Please indicate how strongly you agree or disagree with each of the following statements about your classroom. The children in my classroom...

\begin{tabular}{lcccc} 
& $\begin{array}{c}\text { Strongly } \\
\text { disagree }\end{array}$ & $\begin{array}{c}\text { Somewhat } \\
\text { disagree }\end{array}$ & $\begin{array}{c}\text { Somewhat } \\
\text { agree }\end{array}$ & $\begin{array}{c}\text { Strongly } \\
\text { agree }\end{array}$ \\
\hline Do research based on interests. & 0 & 0 & 0 & 0 \\
Choose their work/activities. & 0 & 0 & $\circ$ & 0 \\
Decide if they will do a follow-up activity. & 0 & 0 & 0 & 0 \\
Determine how long to work with an activity. & 0 & 0 & 0 & 0 \\
Decide where they will work. & 0 & 0 & 0 & 0 \\
May choose to work alone or with others. & 0 & 0 & 0 & 0 \\
Make history timelines. & 0 & 0 & 0 & 0 \\
Create their own math problems. & 0 & 0 & 0 & 0 \\
Repeat Montessori science experiments. & 0 & 0 & 0 & 0 \\
Have access to a full set of Montessori materials. & 0 & 0 & $\circ$ & 0 \\
Take part in community service projects. & 0 & 0 & 0 & 0 \\
\hline
\end{tabular}




\section{Appendix B \\ Teacher Questionnaire of Montessori Practices: Early Childhood References by Item}

\begin{tabular}{|c|c|c|c|c|}
\hline \multirow{2}{*}{$\begin{array}{l}\text { Montessori } \\
\text { Logic Model } \\
\text { inputs* }\end{array}$} & \multirow[b]{2}{*}{ Teacher Questionnaire items } & \multicolumn{3}{|c|}{ References by source type } \\
\hline & & $\begin{array}{l}\text { Organizational } \\
\text { standards }\end{array}$ & $\begin{array}{l}\text { Dr. Maria Montessori } \\
\text { and associates }\end{array}$ & Other publications \\
\hline \multirow[b]{2}{*}{$\begin{array}{l}\text { Mixed age } \\
\text { grouping across a } \\
\text { 3-year age span }\end{array}$} & $\begin{array}{l}\text { [Children] are evenly spread across at } \\
\text { least a 3-yr age span. (Q7.7) }\end{array}$ & \multirow{2}{*}{$\begin{array}{l}\frac{\text { AMI/USA }}{-2009, \text { p. } 13-15} \\
\frac{\text { AMS }}{-2014, \text { p. } 7} \\
\frac{\text { MAFL }}{-2012, \text { p. } 17,19,23,34} \\
51,55,76 \\
\frac{\text { MPPI }}{-2015, \text { p. } 2} \\
\frac{\text { NCMPS }}{-2015, \text { p. } 2}\end{array}$} & \multirow[t]{2}{*}{$\begin{array}{l}\text { Montessori, M. } \\
-1964, \text { p. } 373 \\
-1988, \text { p. } 329 \\
-1989 \text {, p. } 194,225-228 \\
-2008 \text {, p. } 65\end{array}$} & \multirow{2}{*}{$\begin{array}{l}\text { Chattin-McNichols, J. } \\
\text { - 1992, p. 166, 168-169 } \\
\text { Lillard, A.S. } \\
\text { - 2005, p. 20, 144-145, 201-203, } 304 \\
\text { Lillard, P.P. } \\
\text { - 1972, p. } 75 \\
\text { - 1996, p. 34, 39, 41 } \\
\text { Pendersen \& Pendersen } \\
\text { - 2008, p. 23, 38 } \\
\text { Rambusch \& Stoops } \\
\text { - 1992, p. } 37\end{array}$} \\
\hline & There are at least 3 age levels. (Q4.2) & & & \\
\hline $\begin{array}{l}\text { 3-hour } \\
\text { uninterrupted work } \\
\text { periods }\end{array}$ & $\begin{array}{l}\text { There is a three-hour uninterrupted } \\
\text { work period. (Q6.3) }\end{array}$ & $\begin{array}{l}\frac{\text { AMI/USA }}{-2009, \text { p. } 22-26} \\
\frac{\text { AMS }}{-2014, \text { p. } 8-9} \\
\frac{\text { MAFL }}{-2012, \text { p. } 17,18,34,52} \\
53 \\
\frac{\text { MPPI }}{-2015, \text { p. } 1} \\
\frac{\text { NCMPS }}{-2015, \text { p. } 2}\end{array}$ & $\begin{array}{l}\text { Montessori, M. } \\
-1963, \text { p. } 57,67,68,88 \\
\text { - 1965b, p. } 50,81 \\
\text { - 1976, p. } 82,135-136 \\
\text { - 1988, p. } 85 \\
\text { - 1989, p. } 241,272,279 \\
\text { - 1997, p. } 32,35 \\
\text { - 2008, p. 5, 8, 16, 19, } 21 \\
\text { Montessori, M.M. } \\
\text { - 1976, p. } 41 \\
\text { Standing, E.M. } \\
\text { - } 1984, \text { p. } 292 \\
\end{array}$ & $\begin{array}{l}\text { Chattin-McNichols, J. } \\
\text { - } 1992, \text { p. } 16 \\
\text { Daoust, C. } \\
\text { - 2004, p. } 60-62,112,113 \\
\text { Lillard, A.S. } \\
\text {-2005, p. } 73-74,108-110,300,304 \\
\text { Lillard, P.P. } \\
\text { - } 1972, \text { p. } 54,57,65,87 \\
\text { - 1980, p. } 12 \\
\text { Pendersen \& Pendersen } \\
\text { - 2008, p. } 24\end{array}$ \\
\hline \multirow{5}{*}{$\begin{array}{l}\text { Full set of } \\
\text { Montessori } \\
\text { materials }\end{array}$} & $\begin{array}{l}\text { A full set of Montessori materials is } \\
\text { available. (Q4.1) }\end{array}$ & \multirow{5}{*}{$\begin{array}{l}\frac{\text { AMI/USA }}{-2009, p .10} \\
\frac{\text { AMS }}{-2014, \text { p. } 6,8} \\
\frac{\text { MAFL }}{-2012, \text { p. } 22,51} \\
\frac{\text { MPPI }}{-2015, \text { p. } 1} \\
\frac{\text { NCMPS }}{-2015, \text { p. } 3}\end{array}$} & \multirow{5}{*}{$\begin{array}{l}\text { Montessori, M. } \\
\text { - 1965a, p. } 50-57 \text { etc. } \\
\text { - 1970, p. } 155-156 \\
-1988 \text {, p. } 107 \\
-1989, \text { p. } 223 \\
\text { - 1997, p. } 13,295 \\
\text { - 2008, p. } 23,64\end{array}$} & \multirow{5}{*}{$\begin{array}{l}\text { Haines A.M. } \\
\text { - } 1997, \text { p. } 30-31,84-88,90 \\
\text { Lillard, A.S. } \\
\text { - 2005, p. } 18,21-22,97,252 \\
\text { Lillard, P.P. } \\
\text { - 1972, p. } 58,70-74 \\
\text { - 1996, p.40 } \\
\text { Pendersen \& Pendersen } \\
\text { - 2008, p. } 28\end{array}$} \\
\hline & $\begin{array}{l}\text { Art materials are available all day. } \\
\text { (Q4.5) }\end{array}$ & & & \\
\hline & A polishing activity is available. (Q4.7) & & & \\
\hline & $\begin{array}{l}\text { Older children do golden bead addition. } \\
\text { (Q6.9) }\end{array}$ & & & \\
\hline & $\begin{array}{l}\text { [Children] regularly use the Montessori } \\
\text { bells. (Q7.9) }\end{array}$ & & & \\
\hline $\begin{array}{l}\text { Small group / one- } \\
\text { on-one instruction }\end{array}$ & $\begin{array}{l}\text { Lessons are mostly given to } \\
\text { individuals. (Q6.4) }\end{array}$ & $\begin{array}{l}\frac{\text { AMI/USA }}{-2009, \text { p. } 6,8,9} \\
\frac{\text { AMS }}{-2014, \text { p. } 9} \\
\frac{\text { MAFL }}{-2012, \text { p. } 21,23,34} \\
\frac{\text { MPPI }}{-2015, \text { p. } 2} \\
\frac{\text { NCMPS }}{-2015, \text { p. } 3}\end{array}$ & 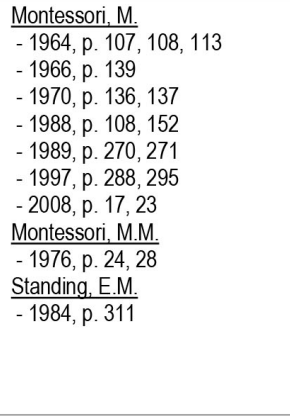 & $\begin{array}{l}\text { Chattin-McNichols, J. } \\
\text { - 1992, p. 53, 56-57, 60, 66, } 93 \\
\text { Daoust, C. } \\
\text { - 2004, p. } 114,115 \\
\text { Joosten, A.M. } \\
\text {-2013, p. 12-13, } 15 \\
\text { Lillard, A.S. } \\
\text { - 2005, p. 21, 141, } 146 \\
\text { Lillard, P.P. } \\
\text { - 1972, p. 54, 55, 60, } 65 \\
\text { - 1980, p. 11, 15 } \\
\text { Pendersen \& Pendersen } \\
\text { - 2008, p. 24 } \\
\text { Rambusch \& Stoops } \\
\text { - 1992, p. } 36\end{array}$ \\
\hline & $\begin{array}{l}\text { [Children] choose their work / activities. } \\
\text { (Q7.5) }\end{array}$ & \multirow{2}{*}{$\begin{array}{l}\frac{\text { AMI/USA }}{-2009, \text { p. } 25} \\
\frac{\text { AMS }}{-2014, \text { p. } 6} \\
\frac{\text { MAFL }}{-2012, \text { p. } 15,16,18,20,} \\
21,25 \\
\frac{\text { MPPI }}{-2015, \text { p. } 2,3} \\
\frac{\text { NCMPS }}{-2015, \text { p. } 3}\end{array}$} & \multirow{2}{*}{$\begin{array}{l}\text { Montessori, M. } \\
\text { - 1965a, p. } 131 \\
\text { - 1965b, p. } 71 \\
\text { - 1966, p. } 111,121,139 \\
\text { - 1988, p. } 65,99,150 \\
\text { - 1989, p. } 207,223 \\
\text { - 1997, p. } 13,30,61,291 \\
\text { - 2008, p. } 18,26 \\
\text { Montessori, M.M. } \\
\text { - } 1976, \text { p. } 43\end{array}$} & \multirow{2}{*}{$\begin{array}{l}\text { Chattin-McNichols, J. } \\
\text { - 1992, p. 44, 54, 66, 160, } 168 \\
\text { Lillard, A.S. } \\
\text { - 2005, p. } 30,74,80,90,98,101-102 \text {, } \\
\text { 326 } \\
\text { Lillard, P.P. } \\
\text { - 1972, p. } 54,55 \\
\text { - 1980, p. 12 } \\
\text { Pendersen \& Pendersen } \\
\text { - 2008, p. 24 } \\
\text { Rambusch \& Stoops } \\
\text { - 1992, p. 36, } 43\end{array}$} \\
\hline $\begin{array}{l}\text { Extensive student } \\
\text { choice }\end{array}$ & May choose to skip circle time. (Q4.3) & & & \\
\hline
\end{tabular}




\begin{tabular}{|c|c|c|c|c|}
\hline \multirow{2}{*}{$\begin{array}{l}\text { Montessori } \\
\text { Logic Model } \\
\text { inputs* }\end{array}$} & \multirow[b]{2}{*}{ Teacher Questionnaire items } & \multicolumn{3}{|c|}{ References by source type } \\
\hline & & $\begin{array}{l}\text { Organizational } \\
\text { standards }\end{array}$ & $\begin{array}{l}\text { Dr. Maria Montessori } \\
\text { and associates }\end{array}$ & Other publications \\
\hline \multirow{4}{*}{$\begin{array}{l}\text { Extensive student } \\
\text { choice (continued) }\end{array}$} & $\begin{array}{l}\text { [Children] may choose to work alone or } \\
\text { with others. (Q7.1) }\end{array}$ & $\begin{array}{l}\frac{\text { AMI/USA }}{-2009, \text { p. } 13.18} \\
\frac{\text { AMS }}{-2014, \text { p. } 9} \\
\frac{\text { MAFL }}{-2012, \text { p. } 19,24,51}\end{array}$ & $\begin{array}{l}\text { Montessori, M. } \\
-1988, \text { p. } 86 \\
\text { - 1989, p. 228, } 231 \\
\text { - 1997, p. } 291 \\
\text { - 2008, p. } 22,24 \\
\text { - 2013, p. 12, 18 } \\
\text { Montessori, M.M. } \\
\text { - 1976, p. 28-29, } 95\end{array}$ & $\begin{array}{l}\text { Chattin-McNichols, J. } \\
\text { - 1992, p. 44, } 86 \\
\text { Lillard, A.S. } \\
\text { - 2005, p. } 21,29,30,32,74,193,209- \\
210 \\
\text { Lillard, P.P. } \\
\text { - 1972, p. } 55 \\
\text { Pendersen \& Pendersen } \\
\text { - 2008, p. 25, 38 } \\
\frac{\text { Rambusch \& Stoops }}{-1992, \text { p. 37, 43 }}\end{array}$ \\
\hline & Snack is a self-serve activity.(4.4) & $\frac{\text { MAFL }}{-2012, \text { p. } 35}$ & & $\begin{array}{l}\text { Chattin-McNichols, J. } \\
\text { - 1992, p. } 16,50 \\
\text { Daoust, C. } \\
\text {-2004, p. } 113,115 \\
\text { Lillard, A. S. } \\
-2005, \text { p. } 48\end{array}$ \\
\hline & $\begin{array}{l}\text { [Children] determine how long to work } \\
\text { with an activity. (Q7.6) }\end{array}$ & $\begin{array}{l}\frac{\text { MAFL }}{-2012, \text { p. } 18,21,75} \\
\frac{\text { NCMPS }}{-2015, \text { p. } 2,3}\end{array}$ & $\begin{array}{l}\text { Montessori, M. } \\
-1965 \text { b, p. } 71 \\
-1988, \text { p. } 98,163 \\
-1989, \text { p. } 199\end{array}$ & $\begin{array}{l}\frac{\text { Joosten, A.M. }}{-2013, \text { p. } 19} \\
\text { Lillard, A.S. } \\
-2005, \text { p. } 80,91 \\
\text { Rambusch \& Stoops } \\
-1992, \text { p. } 36,43\end{array}$ \\
\hline & $\begin{array}{l}\text { [Children] decide where they will work. } \\
\text { (Q7.2) }\end{array}$ & $\begin{array}{l}\frac{\text { MAFL }}{-2012, \text { p. } 18} \\
\frac{\text { MPPI }}{-2015, \text { p. } 2} \\
\frac{\text { NCMPS }}{-2015, \text { p. } 3}\end{array}$ & $\begin{array}{l}\text { Montessori, M. } \\
\text { - 1988, p. } 98 \\
\text { - 1997, p. } 29 \\
\text { - 2008, p. } 67 \\
\text { - 2013, p. } 16,18\end{array}$ & $\begin{array}{l}\text { Lillard, A.S. } \\
\text { - 2005, p. } 21 \\
\text { Pendersen \& Pendersen } \\
-2008, \text { p. } 26 \\
\text { Standing, E.M. } \\
\text { - 1984, p. } 277\end{array}$ \\
\hline $\begin{array}{l}\text { Larger classes / } \\
\text { higher child to } \\
\text { teacher ratios }\end{array}$ & $\begin{array}{l}\text { At least } 25 \text { children typically attend } \\
\text { each day. (Q4.8) }\end{array}$ & $\begin{array}{l}\frac{\text { AMI/USA }}{-2009, p . ~} 18-20 \\
\frac{\text { AMS }}{-2014, \text { p. } 8} \\
\frac{\text { MPPI }}{-2015, \text { p. } 2}\end{array}$ & $\begin{array}{l}\frac{\text { Montessori, M. }}{\text { - 1972, p. } 92} \\
\text { - 1988, p. } 114,302 \\
\text { - 2008, p. } 45,64-65 \\
\text { - 2013, p. } 14 \\
\text { Standing, E.M. } \\
\text { - } 1984 \text {, p. } 277-278\end{array}$ & $\begin{array}{l}\frac{\text { Lillard, A.S. }}{-2005, \text { p. } 202} \\
\text { Lillard, P.P. } \\
\text { - 1996, p. 34, } 40 \\
\text { Pendersen \& Pendersen } \\
\text { - 2008, p. } 23\end{array}$ \\
\hline \multirow{6}{*}{$\begin{array}{l}\text { Montessori } \\
\text { classroom design } \\
\text { and pedagogy }\end{array}$} & $\begin{array}{l}\text { Breakable materials are available. } \\
\text { (Q6.5) }\end{array}$ & $\begin{array}{l}\frac{\mathrm{MAFL}}{-2012, \text { p. } 35} \\
\frac{\text { NCMPS }}{-2015, \text { p. } 3}\end{array}$ & $\begin{array}{l}\text { Montessori, M. } \\
\text { - 1965a, p. } 43 \\
\text { - 1965b, p. } 121,250 \\
-1970, \text { p. } 97-98 \\
\text { - 1997, p. 200-202, 330-332 }\end{array}$ & $\begin{array}{l}\text { Chattin-McNichols, J. } \\
\text { - 1992, p. 74, 75, 76, } 83 \\
\text { Lillard, P.P. } \\
\text { - 1972, p. 58, } 59 \\
\text { Pendersen \& Pendersen } \\
\text { - 2008, p. } 29\end{array}$ \\
\hline & $\begin{array}{l}\text { [Children] garden in a designated area. } \\
\text { (Q7.10) }\end{array}$ & $\begin{array}{l}\frac{\text { MAFL }}{-2012, \text { p. }} 50,66 \\
\frac{\text { NCMPS }}{-2015, \text { p. } 3}\end{array}$ & $\begin{array}{l}\text { Montessori, M. } \\
-1964, \text { p. } 157-159 \\
\text { - 1965a, p. } 60 \\
\text { - 1988, p. } 84 \\
\text { - } 2013, \text { p. } 14,17-18\end{array}$ & $\frac{\text { Lillard, P.P. }}{-1972, \text { p. } 59}$ \\
\hline & $\begin{array}{l}\text { Classroom books feature realistic } \\
\text { stories. (Q6.6) }\end{array}$ & $\frac{\text { MAFL }}{-2012, \text { p. } 56,57}$ & & $\begin{array}{l}\text { Lillard, A.S. } \\
-2005, \text { p. } 185\end{array}$ \\
\hline & Children regularly prepare food. (Q6.7) & $\begin{array}{l}\frac{\text { MAFL }}{-2012, \text { p. } 49,55,64,} \\
\frac{\text { NCMPS }}{-2015, \text { p. } 3}\end{array}$ & & $\begin{array}{l}\frac{\text { Chattin-McNichols, J. }}{\text { - 1992, p. 50, 53, 73, } 75} \\
\text { Lillard, A.S. } \\
\text { - 2005, p. } 48 \\
\text { Lillard, P.P. } \\
\text { - 1972, p. } 58\end{array}$ \\
\hline & $\begin{array}{l}\text { Children give lessons to one another. } \\
\text { (Q4.6) }\end{array}$ & $\begin{array}{l}\frac{\text { AMI/USA }}{-2009, p .} 2,13,14,18 \\
\frac{\text { MAFL }}{-2012, \text { p. } 19,51}\end{array}$ & $\begin{array}{l}\text { Montessori, M. } \\
-1989, \text { p. } 228 \\
\text { - 2008, p. } 68-69 \\
\text { Standing, E.M. } \\
\text { - } 1984 \text {, p. } 278\end{array}$ & $\begin{array}{l}\text { Lillard, A.S. } \\
\text { - 2005, p. } 209 \\
\text { Lillard, P.P. } \\
\text { - 1972, p. } 76 \\
\text { Pendersen \& Pendersen } \\
\text { - 2008, p. 25, } 38\end{array}$ \\
\hline & $\begin{array}{l}\text { [Children] walk on the line carrying } \\
\text { objects. (Q7.8) }\end{array}$ & $\frac{\text { MAFL }}{-2012, \text { p. } 50,78}$ & $\begin{array}{l}\text { Montessori, M. } \\
\text { - 1965a, p. 63-64 } \\
\text { - 1988, p. } 92 \\
\text { Standing, E.M. } \\
\text { - 1984, p. 224-225 }\end{array}$ & $\frac{\text { Lillard, P.P. }}{-1972, \text { p. } 127}$ \\
\hline
\end{tabular}




\begin{tabular}{|c|c|c|c|c|}
\hline \multirow{2}{*}{$\begin{array}{l}\text { Montessori } \\
\text { Logic Model } \\
\text { inputs* }\end{array}$} & \multirow[b]{2}{*}{ Teacher Questionnaire items } & \multicolumn{3}{|c|}{ References by source type } \\
\hline & & $\begin{array}{l}\text { Organizational } \\
\text { standards }\end{array}$ & $\begin{array}{l}\text { Dr. Maria Montessori } \\
\text { and associates }\end{array}$ & Other publications \\
\hline \multirow{2}{*}{$\begin{array}{l}\text { Montessori } \\
\text { classroom design } \\
\text { and pedagogy } \\
\text { (continued) }\end{array}$} & $\begin{array}{l}\text { [Children] care for classroom plants. } \\
\text { (Q7.3) }\end{array}$ & \multirow[t]{2}{*}{$\begin{array}{l}\frac{\text { MAFL }}{-2012, \text { p. } 34,50,65,66} \text {, } \\
\quad 67\end{array}$} & \multirow{2}{*}{$\begin{array}{l}\text { Montessori, M. } \\
\text { - 1964, p. } 157-158 \\
\text { - 1965b, p. } 161 \\
\text { - 1988, p. } 73-77,84 \\
\text { - 2013, p. } 17 \\
\text { Montessori, M.M. } \\
\text { - 1964, p. } 29\end{array}$} & \multirow{2}{*}{$\begin{array}{l}\text { Joosten, A.M. } \\
\text { - 2013, p. 23, 27, 28, } \\
\text { Lillard, A.S. } \\
\text { - 2005, p. } 48,310 \\
\text { Lillard, P.P. } \\
\text { - 1972, p. } 58-59,74 \\
\text { Pendersen \& Pendersen } \\
\text { - 2008, p. 25, 26, 35 }\end{array}$} \\
\hline & $\begin{array}{l}\text { [Children] care for classroom animals. } \\
\text { (Q7.4) }\end{array}$ & & & \\
\hline \multirow{2}{*}{$\begin{array}{l}\text { Teacher } \\
\text { observation, } \\
\text { ongoing } \\
\text { assessment }\end{array}$} & $\begin{array}{l}\text { Children's activities are recorded each } \\
\text { day. (Q6.2) }\end{array}$ & $\begin{array}{l}\frac{\text { AMS }}{-2014, \text { p. } 9} \\
\frac{\text { MAFL }}{-2012, \text { p. } 21,23-25} \\
\frac{\text { MPPI }}{-2015, \text { p. } 2} \\
\frac{\text { NCMPS }}{-2015, \text { p. } 8}\end{array}$ & $\begin{array}{l}\frac{\text { Montessori, M. }}{-2013, \text { p. } 19} \\
\frac{\text { Montessori, M.M. }}{-1976, \text { p. } 44}\end{array}$ & $\begin{array}{l}\frac{\text { Joosten, A.M. }}{-2013, \text { p. } 19} \\
\text { Lillard, A.S. } \\
\text { - 2005, p. } 142 \\
\text { Pendersen \& Pendersen } \\
\text { - 2008, p. 23, } 31\end{array}$ \\
\hline & $\begin{array}{l}\text { Observation is used for daily lesson } \\
\text { planning. (Q6.1) }\end{array}$ & $\begin{array}{l}\frac{\text { AMS }}{-2014, \text { p. } 4,9} \\
\text { MAFL } \\
-2012, \text { p. } 21,23,24,32 \\
\frac{\text { NCMPS }}{-2015, \text { p. } 8}\end{array}$ & $\begin{array}{l}\text { Montessori, M. } \\
-1964, \text { p. } 108 \\
\text { - 1970, p. } 139 \\
\text { - 1988, p. } 109,151 \\
\text { - 1997, p. } 138,288 \\
\text { - 2013, p. } 19 \\
\text { Standing. E.M. } \\
\text { - } 1984 \text {, p. } 293,310\end{array}$ & $\begin{array}{l}\text { Lillard, A.S. } \\
\text { - 2005, p. 141-142, } 282 \\
\text { Lillard, P.P. } \\
\text { - 1972, p. 60, 79-82 } \\
\text { Pendersen \& Pendersen } \\
\text { - 2008, p. 23, } 31\end{array}$ \\
\hline
\end{tabular}

*Aligned with inputs from the Logic Model for Montessori Education (Culclasure, Daoust, Morris Cote, \& Zoll, 2019).

Note. Logic Model inputs of Credentialed Teachers, Continuing Professional Development, and Diverse Population of Students were not asked as Likert items in the Teacher Questionnaire. They were asked as direct questions about teacher and classroom characteristics in another section and will be included in future analysis.

\section{References}

\section{Standards}

AMI/USA = Association Montessori International/USA. (2009). AMI/USA Montessori school standards. Alexandria, VA: AMI/USA

AMS = American Montessori Society. (2014). AMS school accreditation standards and criteria.

MAFL = Montessori Australia Foundation Limited (2012). Montessori National Curriculum. The NAMTA Journal, 37(1).

NCMPS = National Center for Montessori in the Public Sector. (2015). Essential elements on Montessori practice in the public sector.

MPPI = Montessori Public Policy Initiative. (2015). Montessori essentials.

\section{Montessori and Others}

Chattin-McNichols, J. (1992). The Montessori controversy. Albany, NY: Delmar.

Haines, A. M. (1997). Universal interest levels in early childhood: Montessori's theory of sensitive periods (Doctoral dissertation). Southern Illinois University, Edwardsville, IL.

Daoust, C. (2004). An examination of implementation practices in Montessori early childhood education (Doctoral dissertation). University of California, Berkeley, CA.

Joosten, A. M. (2013). Exercises of practical life: introduction and list. The NAMTA Journal, (38)2, pp. 4-34

Lillard, A. S. (2005). Montessori: The science behind the genius. New York: Oxford University Press.

Lillard, P. P. (1972). Montessori: A modem approach. New York: Schocken.

Lillard, P. P. (1980). Montessori in the classroom. New York: Schocken.

Lillard, P. P. (1996). Montessori today. New York: Schocken.

Montessori, M. (1963). Education for a new world. Madras, India: Kalakshetra.

Montessori. M. (1964). The Montessori Method. New York: Schocken.

Montessori, M. (1965a). Dr. Montessori's own handbook. New York: Schocken.

Montessori, M. (1965b). Spontaneous activity in education: The advanced Montessori Method. Madras, India: Kalakshetra.

Montessori, M. (1966). The secret of childhood. New York: Ballantine Books.

Montessori, M. (1970). The child in the family. New York: Avon.

Montessori, M. (1972). Education and peace (H. R. Lane, Trans.). Washington DC: Henry Regnery.

Montessori M. (1973). To educate the human potential. Madras, India: Kalakshetra

Montessori, M. (1976). What you should know about your child. Madras, India: Kalakshetra.

Montessori, M. (1988). The discovery of the child. Oxford, England, Clio Press.

Montessori, M. (1989). The absorbent mind. New York: Dell.

Montessori. M. (1997). The California lectures of Maria Montessori, 2015. Oxford: Clio.

Montessori, M. (2008). The child, society, and the world: Unpublished speeches and writings. Amsterdam, Netherlands: Montessori-Pierson

Montessori, M. (2013). The house of children: lecture, Kodaikanal, 1944 [Special issue]. The NAMTA Joumal, (38)1, pp. 10-19.

Montessori. M. M. (1976). Education for human development. New York: Schocken.

Pendersen, H. \& Pendersen, J. (2008). What is Montessori? A basic guide to the principles, practices, and benefits of a Montessori education. San Anselmo, CA: Sandpiper Press

Rambusch, N. M. \& Stoops, J. A. (1992). The authentic American Montessori school: A guide to the self-study, evaluation, and accreditation of American schools committed to Montessori education. New York: AMS and the Commission on Elementary Schools of the Middle States Association.

Standing, E. M. (1957/1984). Maria Montessori: Her life and work. New York: New American Library. 


\section{Appendix C \\ Teacher Questionnaire of Montessori Practices: Elementary References by Item}

\begin{tabular}{|c|c|c|c|c|}
\hline \multirow[b]{2}{*}{$\begin{array}{l}\text { Montessori Logic } \\
\text { Model inputs* }\end{array}$} & \multirow[b]{2}{*}{ Teacher Questionnaire items } & \multicolumn{3}{|c|}{ References by source type } \\
\hline & & $\begin{array}{l}\text { Organizational } \\
\text { standards }\end{array}$ & $\begin{array}{l}\text { Dr. Maria Montessori } \\
\text { and associates }\end{array}$ & Other publications \\
\hline $\begin{array}{l}\text { Mixed age grouping } \\
\text { across a 3-year age } \\
\text { span }\end{array}$ & $\begin{array}{l}\text { Children are in at least } 3 \text { grade levels. } \\
\text { (Q4.1) }\end{array}$ & $\begin{array}{l}\frac{\text { AMI/USA }}{-2009, \text { p. } 13-15} \\
\frac{\text { AMS }}{-2014, \text { p. } 7} \\
\frac{\text { MAFL }}{-2012, \text { p. } 17,19,23,240} \\
\frac{\text { MPPI }}{-2015, \text { p. } 2} \\
\frac{\text { NCMPS }}{-2015, \text { p. } 2}\end{array}$ & $\begin{array}{l}\text { Montessori, M. } \\
\text { - 1964, p. } 373 \\
\text { - } 1988 \text {, p. } 329 \\
\text { - } 1989 \text {, p. } 194,225-228 \\
\text { - } 2008 \text {, p. } 65,68-69\end{array}$ & $\begin{array}{l}\text { Chattin-McNichols, J. } \\
\text { - 1992, p. 166, 168-169, } 209 \\
\text { Grazzini, B.K. } \\
\text {-2010, p. 84 } \\
\text { Lillard, A.S. } \\
\text {-2005, p. 20, 201-203, } 304 \\
\text { Lillard, P.P. } \\
\text {-1996, p. 78, 87 } \\
\text { Pendersen \& Pendersen } \\
\text { - 2008, p. 23, 38 } \\
\frac{\text { Rambusch \& Stoops }}{-1992, \text { p. } 37}\end{array}$ \\
\hline $\begin{array}{l}\text { 3-hour } \\
\text { uninterrupted work } \\
\text { periods }\end{array}$ & $\begin{array}{l}\text { There is a 3-hour uninterrupted work } \\
\text { period. (Q6.6) }\end{array}$ & $\begin{array}{l}\frac{\text { AMI/USA }}{-2009, \text { p. } 22-26} \\
\frac{\text { AMS }}{-2014, \text { p. } 8-9} \\
\frac{\text { MAFL }}{-2012, \text { p. } 17,18,88,209,} \\
211 \\
\frac{\text { MPPI }}{-2015, \text { p. } 1} \\
\frac{\text { NCMPS }}{-2015, \text { p. } 2}\end{array}$ & $\begin{array}{l}\text { Montessori, M. } \\
-1965, \text { p. } 50,81 \\
\text { - 1976, p. } 82,135-136 \\
-1988, \text { p. } 85 \\
-1989, \text { p. } 241,272 \\
\text { - 1997, p. } 13,34,35 \\
\text { - 2008, p. } 5,8,32 \\
\text { Montessori, M.M. } \\
\text { - 1976, p. } 41 \\
\text { Standing E.M. } \\
\text { - } 1984, \text { p. } 292\end{array}$ & $\begin{array}{l}\text { Chattin-McNichols, J. } \\
\text { - 1992, p. } 16 \\
\text { Grazzini, B.K. } \\
\text {-2010, p. } 84 \\
\text { Lillard, A.S. } \\
\text { - 2005, p. } 73-74,108-110,300,304 \\
\text { Lillard, P.P. } \\
\text { - 1996, p. 93-94 } \\
\text { Pendersen \& Pendersen } \\
\text { - 2008, p. } 24\end{array}$ \\
\hline \multirow{6}{*}{$\begin{array}{l}\text { Full set of } \\
\text { Montessori } \\
\text { materials }\end{array}$} & $\begin{array}{l}\text { [Children] have access to a full set of } \\
\text { Montessori materials. (7.10) }\end{array}$ & \multirow{3}{*}{$\begin{array}{l}\frac{\text { AMI/USA }}{-2009, \text { p. } 10} \\
\frac{\text { AMS }}{-2014, \text { p. } 6,8} \\
\frac{\text { MAFL }}{-2012, \text { p. } 22,209-214} \\
\frac{\text { MPPI }}{-2015, \text { p. } 1} \\
\frac{\text { NCMPS }}{-2015, \text { p. } 3}\end{array}$} & \multirow{3}{*}{$\begin{array}{l}\text { Montessori, M. } \\
-1970, \text { p. } 155-156 \\
-1988, \text { p. } 107 \\
-1997, \text { p. } 12,29,33 \\
-1997 \text { b, p. } 13,295 \\
\text { - 2008, p. } 64 \\
\text { Montessori, M.M. } \\
\text { - 1976, p. 21, 24, } 69\end{array}$} & \multirow{3}{*}{$\begin{array}{l}\text { Chattin-McNichols, J. } \\
\text { - 1992, p. 54, } \\
\text { Lillard, A. S. } \\
\text { - 2005, p. 18, 21-22, } 252 \\
\text { Pendersen \& Pendersen } \\
\text { - 2008, p. 27(art), } 28 \\
\text { Lillard, P.P. } \\
\text { - 1996, p. } 78\end{array}$} \\
\hline & $\begin{array}{l}\text { Art materials are available all day. } \\
\text { (Q4.10) }\end{array}$ & & & \\
\hline & $\begin{array}{l}\text { Most instruction is given with } \\
\text { Montessori materials. (Q6.9) }\end{array}$ & & & \\
\hline & $\begin{array}{l}\text { There is a full set of large geography } \\
\text { charts. (Q4.12) }\end{array}$ & $\begin{array}{l}\frac{\text { MAFL }}{-2012, \text { p. 96, 183, 189, 190, }} \\
191,203-205,208\end{array}$ & $\frac{\text { Montessori, M. }}{-1976, \text { p. } 39-40,63-64,77,79}$ & $\begin{array}{l}\text { Chattin-McNichols, J. } \\
\text { - 1992, p. 81, 132, 143-144 } \\
\text { Daoust \& Suzuki } \\
\text { - 2014, research poster } \\
\text { Lillard, A.S. } \\
\text { - 2005, p. } 132\end{array}$ \\
\hline & $\begin{array}{l}\text { [Children] repeat Montessori science } \\
\text { experiments. (Q7.9) }\end{array}$ & $\begin{array}{l}\frac{\text { MAFL }}{-2012, \text { p. } 178,179,183,189} \\
\quad 192,203\end{array}$ & & $\frac{\text { Chattin-McNichols, J. }}{-1992, \text { p. } 144}$ \\
\hline & $\begin{array}{l}\text { Children use human fundamental } \\
\text { needs charts. (Q6.3) }\end{array}$ & $\begin{array}{l}\frac{\text { MAFL }}{-2012, \text { p. } 176,180,185,186} \\
\quad 196-198,234,235\end{array}$ & & $\begin{array}{l}\text { Chattin-McNichols, J. } \\
\text { - 1992, p. 142-143, 146, } 149 \\
\text { Daoust \& Suzuki } \\
\text { - 2013, research poster } \\
\text { Lillard, A.S. } \\
\text { - 2005, p. } 71 \\
\text { Lillard, P.P. } \\
\text { - 1996, p. 73-74 }\end{array}$ \\
\hline
\end{tabular}




\begin{tabular}{|c|c|c|c|c|}
\hline \multirow[b]{2}{*}{$\begin{array}{l}\text { Montessori Logic } \\
\text { Model inputs* }\end{array}$} & \multirow[b]{2}{*}{ Teacher Questionnaire items } & \multicolumn{3}{|c|}{ References by source type } \\
\hline & & $\begin{array}{l}\text { Organizational } \\
\text { standards }\end{array}$ & $\begin{array}{l}\text { Dr. Maria Montessori } \\
\text { and associates }\end{array}$ & Other publications \\
\hline \multirow[b]{2}{*}{$\begin{array}{l}\text { Small group / one- } \\
\text { on-one instruction }\end{array}$} & $\begin{array}{l}\text { Most lessons are given in groups of } 2- \\
5 \text { children. (Q6.8) }\end{array}$ & \multirow{2}{*}{$\begin{array}{l}\frac{\text { AMI/USA }}{-2009, \text { p. } 6,8,9} \\
\frac{\text { AMS }}{-2014, \text { p. } 9} \\
\frac{\text { MAFL }}{-2012, \text { p. } 21,23,86,87} \\
\frac{\text { MPPI }}{-2015, \text { p. } 2} \\
\frac{\text { NCMPS }}{-2015, \text { p. } 3} \\
\frac{\text { MAFL }}{-2012, \text { p. } 87,89,160,236,}\end{array}$} & $\begin{array}{l}\text { Montessori, M. } \\
\text { - 1970, p. } 136,137 \\
\text { - 1997b, p. } 288,295 \text {, } \\
\text { Standing E.M. } \\
\text { - 1984, p. } 311\end{array}$ & $\begin{array}{l}\text { Chattin-McNichols, J. } \\
\text {-1992, p. } 57 \\
\text { Lillard, A.S. } \\
-2005, \text { p. } 21 \\
\frac{\text { Pottish-Lewis, P. }}{-2011, \text { p. } 12}\end{array}$ \\
\hline & $\begin{array}{l}\text { Most lessons last } 15 \text { minutes or less. } \\
\text { (Q4.6) }\end{array}$ & & $\begin{array}{l}\frac{\text { Montessori, M. }}{\text {-1964, p. } 107,108} \\
\text { Montessori, M.M. } \\
\text {-1976, p. } 24,28 \\
\text { - 1997, p. } 35\end{array}$ & $\begin{array}{l}\text { Chattin-McNichols, J. } \\
\text { - 1992, p. 55-57,60, } 66 \\
\text { Lillard, A.S. } \\
\text { - 2005, p. 21, 141, } 203 \\
\text { Pendersen \& Pendersen } \\
\text { - 2008, p. 24, 34 } \\
\text { Pottish-Lewis, P. } \\
\text { - 2011, p. 5, 6, 12, } 14 \\
\text { Rambusch \& Stoops } \\
\text {-1992, p. } 36\end{array}$ \\
\hline \multirow{5}{*}{$\begin{array}{l}\text { Extensive student } \\
\text { choice }\end{array}$} & $\begin{array}{l}\text { [Children] choose their work / } \\
\text { activities. (Q7.2) }\end{array}$ & $\begin{array}{l}\frac{\text { AMI/USA }}{-2009, \text { p. } 25} \\
\frac{\text { AMS }}{-2014, \text { p. } 6} \\
\frac{\text { MAFL }}{-2012, \text { p. } 15,16,18,20,21} \\
25,236 \\
\frac{\text { MPPI }}{-2015, \text { p. } 1} \\
\frac{\text { NCMPS }}{-2015, \text { p. } 3}\end{array}$ & \multirow[t]{3}{*}{$\begin{array}{l}\text { Montessori, M. } \\
-1965, \text { p. } 71 \\
-1976, \text { p. } 29 \\
-1988, \text { p. } 65,99,150 \\
-1989, \text { p. } 207,223 \\
\text { - 1997, p. } 27 \\
\text { - 1997b, p. } 13,30,61,291 \\
\text { - 2008, p. } 40-41 \\
\text { - 1973, p. } 7 \\
\text { Montessori, M.M. } \\
\text { - 1976, p. } 43,63 \\
\text { Standing E.M. } \\
-1984, \text { p. } 364,365\end{array}$} & 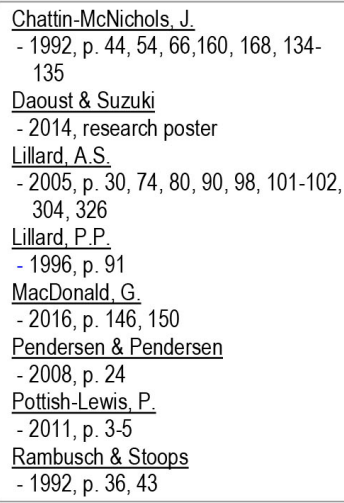 \\
\hline & $\begin{array}{l}\text { [Children] decide if they will do a } \\
\text { follow-up activity. (Q7.3) }\end{array}$ & $\frac{\text { MAFL }}{-2012, \text { p. } 88,179}$ & & $\begin{array}{l}\text { Chattin-McNichols, J. } \\
\text {-1992, p. } 124 \\
\text { Lillard,P.P. } \\
\text {-1996, p. } 91\end{array}$ \\
\hline & $\begin{array}{l}\text { Children decide when to have snack. } \\
\text { (Q4.2) }\end{array}$ & & & $\begin{array}{l}\text { Chattin-McNichols, J. } \\
\text { - 1992, p. 16, } 50 \\
\text { Daoust \& Suzuki } \\
\text { - 2014, research poster }\end{array}$ \\
\hline & $\begin{array}{l}\text { [Children] may choose to work alone } \\
\text { or with others. (Q7.6) }\end{array}$ & $\begin{array}{l}\frac{\text { AMI/USA }}{-2009, \text { p. } 13,18} \\
\frac{\text { AMS }}{-2014, \text { p. } 9} \\
\frac{\text { MAFL }}{-2012, \text { p. } 18,19,24,86,87} \\
\quad 88,99,180\end{array}$ & $\begin{array}{l}\text { Montessori, M. } \\
-1976, \text { p. } 26 \\
\text { - 1989, p. } 235 \\
\text { - 1997b, p. } 291 \\
\text { - 2008, p. } 40 \\
\text { Montessori, M.M. } \\
\text { - 1976, p. 28-29, } 95 \\
\text { Standing E.M. } \\
\text { - 1984, p. 356-367 }\end{array}$ & 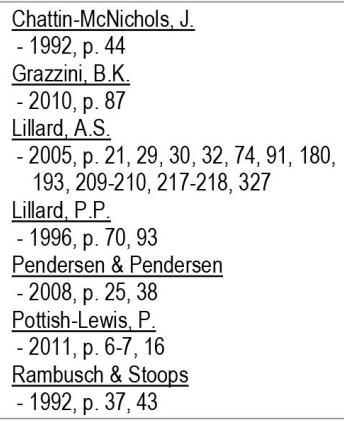 \\
\hline & $\begin{array}{l}\text { [Children] decide where they will work. } \\
\text { (Q7.5) }\end{array}$ & $\begin{array}{l}\frac{\text { MAFL }}{-2012, \text { p. } 18,234} \\
\frac{\text { MPPI }}{-2015, \text { p. } 2} \\
\frac{\text { NCMPS }}{-2015, \text { p. } 3}\end{array}$ & $\begin{array}{l}\frac{\text { Montessori, M. }}{-1988, \text { p. } 98} \\
\text { - 1997b, p. } 291 \\
\text { - 2008, p. } 67-68 \\
\text { Standing E.M. } \\
-1984 \text {, p. } 277\end{array}$ & $\begin{array}{l}\text { Daoust \& Suzuki } \\
\text { - 2014, research poster } \\
\text { Lillard, A.S. } \\
\text {-2005, p. } 21 \\
\text { MacDonald, G. } \\
\text {-2016, p. } 150 \\
\text { Pendersen \& Pendersen } \\
\text { - 2008, p. } 26\end{array}$ \\
\hline
\end{tabular}




\begin{tabular}{|c|c|c|c|c|}
\hline \multirow[b]{2}{*}{$\begin{array}{l}\text { Montessori Logic } \\
\text { Model inputs* }\end{array}$} & \multirow[b]{2}{*}{ Teacher Questionnaire items } & \multicolumn{3}{|c|}{ References by source type } \\
\hline & & $\begin{array}{l}\text { Organizational } \\
\text { standards }\end{array}$ & $\begin{array}{l}\text { Dr. Maria Montessori } \\
\text { and associates }\end{array}$ & Other publications \\
\hline \multirow{5}{*}{$\begin{array}{l}\text { Extensive student } \\
\text { choice (continued) }\end{array}$} & $\begin{array}{l}\text { [Children] determine how long to work } \\
\text { with an activity. (Q7.4) }\end{array}$ & $\begin{array}{l}\frac{\text { MAFL }}{-2012, \text { p. } 18,21,88,236} \\
\frac{\text { NCMPS }}{-2015, \text { p. } 2,3}\end{array}$ & $\begin{array}{l}\text { Montessori, M. } \\
-1965, \text { p. } 71,90 \\
-1988, \text { p. } 98 \\
-1989, \text { p. } 199 \\
-1997, \text { p. } 28 \\
-2008, \text { p. } 40-41\end{array}$ & $\begin{array}{l}\frac{\text { Lillard, A.S. }}{\text {-2005, p. } 80,91,99,102} \\
\text { MacDonald, G. } \\
\text {-2016, p. } 150 \\
\frac{\text { Pottish-Lewis, P. }}{-2011, \text { p. } 16,22} \\
\frac{\text { Rambusch \& Stoops }}{-1992, \text { p. } 36,43}\end{array}$ \\
\hline & $\begin{array}{l}\text { [Children] do research based on } \\
\text { interests. (Q7.1) }\end{array}$ & $\begin{array}{l}\frac{\text { AMS }}{-2014, \text { p. } 5} \\
\frac{\text { MAFL }}{-2012, \text { p. } 17,18,90,179-} \\
180,210\end{array}$ & $\begin{array}{l}\text { Montessori, M. } \\
-1976, \text { p. } 36,38 \\
-1973 \text {, p. } 25 \\
\text { - } 1997, \text { p. } 26,29,33-34 \\
\text { - 2008, p. } 40 \\
\text { Standing E.M. } \\
\text { - } 1984 \text {, p. } 365-366\end{array}$ & $\begin{array}{l}\text { Lillard, A.S. } \\
\text { - 2005, p. } 71,115,122,128 \\
\text { Lillard, P.P. } \\
\text {-1996, p. } 23,91 \\
\text { MacDonald, G. } \\
\text {-2016, p. 146 } \\
\frac{\text { Pendersen \& Pendersen }}{-2008, \text { p. } 24} \\
\text { Pottish-Lewis, P. } \\
\text { - 2011, p. 5, 16, } 17\end{array}$ \\
\hline & $\begin{array}{l}\text { Children help make classroom rules / } \\
\text { guidelines. (Q4.9) }\end{array}$ & $\frac{\text { MAFL }}{-2012, \text { p. } 99,235,237,240}$ & & \\
\hline & $\begin{array}{l}\text { Small groups do "going out" } \\
\text { excursions. (Q4.5) }\end{array}$ & $\begin{array}{l}\frac{\text { AMS }}{-2014, \text { p. } 5} \\
\frac{\text { MAFL }}{-2012, \text { p. } 89,99,100} \\
118,183,185,186 \\
187,191-193,196-200 \\
202-208,210\end{array}$ & $\begin{array}{l}\frac{\text { Montessori, M. }}{-1972, \text { p. } 81} \\
-1976, \text { p. } 25,26,28,33,34 \\
35 \\
\text { Standing E.M. } \\
\text { - } 1984 \text {, p. } 353-355\end{array}$ & $\begin{array}{l}\text { Lillard, A.S. } \\
\text { - 2005, p. } 72-73,91,122,132,225 \text {, } \\
253 \\
\text { Lillard, P.P. } \\
\text { - 1996, p. 58, 102-111 } \\
\text { Pendersen \& Pendersen } \\
\text { - 2008, p. } 27\end{array}$ \\
\hline & $\begin{array}{l}\text { Children develop a system for } \\
\text { classroom maintenance. (Q6.4) }\end{array}$ & $\frac{\text { MAFL }}{-2012, \text { p. } 234}$ & & $\begin{array}{l}\text { Chattin-McNichols, J. } \\
\text {-1992, p. } 80 \\
\text { Lillard, P.P. } \\
-1996, \text { p. 101, } 102 \\
\text { Pottish-Lewis, P. } \\
\text { - 2011, p. 21, 22 }\end{array}$ \\
\hline \multirow{4}{*}{$\begin{array}{l}\text { Montessori } \\
\text { classroom design } \\
\text { and pedagogy }\end{array}$} & $\begin{array}{l}\text { Montessori Great Lessons / Stories } \\
\text { are given each fall. (Q6.1) }\end{array}$ & $\begin{array}{l}\frac{\text { MAFL }}{-2012, \text { p. } 87-88,91,} \\
176,179,183,184, \\
189,195-197,\end{array}$ & $\begin{array}{l}\text { Montessori, M. } \\
-1973, \text { p. } 8-10,16 \\
-1976, \text { p. } 37,49 \\
-2008, \text { p. } 47,49\end{array}$ & $\begin{array}{l}\frac{\text { Chattin-McNichols, J. }}{\text { - 1992, p. 143-145 }} \\
\text { Daoust \& Suzuki } \\
\text { - 2014, research poster } \\
\text { Grazzini, B.K. } \\
\text { - 2010, p. 88-92 } \\
\text { Lillard, A.S. } \\
\text { - 2005, p. 129-135 } \\
\text { Lillard, P.P } \\
\text { - 1996, p. 54-76 } \\
\frac{\text { Pottish-Lewis, P. }}{\text { - 2011, p. } 22}\end{array}$ \\
\hline & $\begin{array}{l}\text { [Children] make history timelines. } \\
(Q .7 .7)\end{array}$ & $\begin{array}{l}\frac{\text { MAFL }}{-2012, p .181,183,184} \\
185,186\end{array}$ & & $\begin{array}{l}\text { Chattin-McNichols, J. } \\
\text {-1992, p. } 145 \\
\text { Lillard, A.S. } \\
\text { - 2005, p. } 133 \\
\text { Lillard, P.P. } \\
-1996, \text { p. } 72\end{array}$ \\
\hline & All children go out for recess. (Q4.3) & \multirow[t]{2}{*}{$\frac{\text { MAFL }}{-2012, \text { p. } 87,89,235}$} & \multirow{2}{*}{$\begin{array}{l}\text { Montessori, M. } \\
-1965, \text { p. } 261 \\
\text { - 1988, p. } 17-19,61-62 \\
\text { - } 1989, \text { p. } 194,244-24 \\
\text { - 1997, p. } 43-44 \\
\text { - 1997b, p. } 277,286,329 \\
\text { - 2008, p. } 28-30 \\
\text { Standing E.M. } \\
\text { - } 1984 \text {, p. } 310\end{array}$} & \multirow{2}{*}{$\begin{array}{l}\frac{\text { Chattin-McNichols, J. }}{-1992, \text { p. } 64,89-90} \\
\text { Kahn, D. } \\
-1995, \text { p. } 11 \\
\text { Lillard, A.S. } \\
-2005, \text { p. } 182 \\
\text { Lillard, P.P. } \\
-1972, \text { p. } 55 \\
\text { MacDonald, G. } \\
\text { - 2016, p. } 148-149\end{array}$} \\
\hline & $\begin{array}{l}\text { Problem-solving with students } \\
\text { addresses off-task behavior. (Q4.7) }\end{array}$ & & & \\
\hline
\end{tabular}




\begin{tabular}{|c|c|c|c|c|}
\hline \multirow[b]{2}{*}{$\begin{array}{l}\text { Montessori Logic } \\
\text { Model inputs* }\end{array}$} & \multirow[b]{2}{*}{ Teacher Questionnaire items } & \multicolumn{3}{|c|}{ References by source type } \\
\hline & & $\begin{array}{l}\text { Organizational } \\
\text { standards }\end{array}$ & $\begin{array}{l}\text { Dr. Maria Montessori } \\
\text { and associates }\end{array}$ & Other publications \\
\hline \multirow{8}{*}{$\begin{array}{l}\text { Montessori } \\
\text { classroom design } \\
\text { and pedagogy } \\
\text { (continued) }\end{array}$} & $\begin{array}{l}\text { 1-on-1 meetings are held at least } \\
\text { every } 2 \text { weeks. (Q4.8) }\end{array}$ & $\begin{array}{l}\frac{\text { NCMPS }}{-2015, \text { p. } 9} \\
\frac{\text { MAFL }}{-2012, \text { p. } 24,87}\end{array}$ & & $\begin{array}{l}\text { Chattin-McNichols, J. } \\
\text {-1992, p. } 135 \\
\text { Lillard, A.S. } \\
\text { - 2005, p. 149-150 } \\
\text { Lillard, P.P. } \\
\text { - 1996, p. } 100 \\
\text { MacDonald, G. } \\
\text { - 2016, p. } 142 \\
\text { Pottish-Lewis, P. } \\
\text { - 2011, p. } 19\end{array}$ \\
\hline & $\begin{array}{l}\text { Children record activities in work } \\
\text { journals. (Q6.5) }\end{array}$ & $\begin{array}{l}\frac{\text { NCMPS }}{-2015, \text { p. } 9} \\
\frac{\text { MAFL }}{-2012, \text { p. } 87}\end{array}$ & & $\begin{array}{l}\text { Lillard, P.P. } \\
\text { - 1996, p. } 97,99,101-102,149,180 \\
\text { Lillard, A.S. } \\
\text { - 2005, p. } 149 \\
\text { Pendersen \& Pendersen } \\
\text { - 2008, p. } 36 \\
\text { Pottish-Lewis, P. } \\
\text { - 2011, p. } 17-19\end{array}$ \\
\hline & $\begin{array}{l}\text { [Children] create their own math } \\
\text { problems. (Q7.8) }\end{array}$ & & & $\frac{\text { MacDonald, G. }}{-2016, \text { p. } 146}$ \\
\hline & $\begin{array}{l}\text { Spelling exercises are individualized. } \\
\text { (Q4.4) }\end{array}$ & $\frac{\text { MAFL }}{-2012, \text { p. } 20}$ & $\frac{\text { Montessori, M. }}{-2008, \text { p. } 87-88}$ & $\begin{array}{l}\frac{\text { Pottish-Lewis, } P}{-2011, \text { p. } 13-14} \\
\text { Rambusch \& Stoops } \\
-1992, \text { p. } 37\end{array}$ \\
\hline & $\begin{array}{l}\text { Children correct their own work. } \\
\text { (Q4.11) }\end{array}$ & $\frac{\text { MAFL }}{-2012, p}$ & & $\begin{array}{l}\text { Chattin-McNichols, J. } \\
\text { - 1992, p. } 55 \\
\text { Lillard, A.S. } \\
\text { - 2005, p. } 176-180\end{array}$ \\
\hline & $\begin{array}{l}\text { Children give lessons to one another. } \\
\text { (Q6.7) }\end{array}$ & $\begin{array}{l}\frac{\text { AMI/USA }}{-2009, \text { p. } 2,13,14,18} \\
\frac{\text { MAFL }}{-2012, \text { p. } 19,51}\end{array}$ & $\frac{\text { Standing E.M. }}{-1984, \text { p. } 278}$ & $\begin{array}{l}\frac{\text { Kahn, D. }}{-1995, \text { p. } 13} \\
\text { Lillard, A.S. } \\
-2005, \text { p. } 180-181,209 \\
\text { Lillard, P.P. } \\
-1972, \text { p. } 76\end{array}$ \\
\hline & $\begin{array}{l}\text { Children regularly prepare food. } \\
\text { (Q6.10) }\end{array}$ & $\begin{array}{l}\text { MAFL } \\
-2012, \text { p. } 235,237 \\
\frac{\text { NCMPS }}{-2015, \text { p. } 3}\end{array}$ & & $\begin{array}{l}\text { Chattin-McNichols, J. } \\
\text { - 1992, p. } 50,53,73,75,79 \\
\text { Lillard, P.P. } \\
\text { - 1972, p. } 58\end{array}$ \\
\hline & $\begin{array}{l}\text { [Children] take part in community } \\
\text { service projects. (Q7.11) }\end{array}$ & $\frac{\text { MAFL }}{-2012, \text { p. } 235,237,240}$ & & $\begin{array}{l}\frac{\text { Kahn, D. }}{-1995, \text { p. } 8} \\
\text { Lillard, P.P. } \\
\text { - 1996, p. 111-112 } \\
\text { Pendersen \& Pendersen } \\
\text {-2008, p. } 39\end{array}$ \\
\hline $\begin{array}{l}\text { Teacher } \\
\text { observation, } \\
\text { ongoing } \\
\text { assessment }\end{array}$ & $\begin{array}{l}\text { Observation is used for daily lesson } \\
\text { planning. (Q6.2) }\end{array}$ & $\begin{array}{l}\frac{\text { AMS }}{-2014, \text { p. } 4,9} \\
\frac{\text { MAFL }}{-2012, \text { p. } 21,23,24} \\
\frac{\text { NCMPS }}{-2015, \text { p. } 8}\end{array}$ & $\begin{array}{l}\text { Montessori, M. } \\
\text { - 1964, p. } 108 \\
\text { - 1970, p. } 139 \\
\text { - 1997b, p. } 138,148-149, \\
\text { 151, 288 } \\
\text { Standing E.M. } \\
\text { - 1984, p. } 293,310\end{array}$ & $\begin{array}{l}\text { Kahn, D. } \\
\text { - } 1995, \text { p. } 7 \\
\text { Lillard, A.S. } \\
\text {-2005, p. 141-142, } 282 \\
\text { Lillard, P.P. } \\
\text { - 1996, p. 72, 91-92 } \\
\text { MacDonald, G. } \\
\text { - 2016, p. 133, 140-141,159 } \\
\text { Pendersen \& Pendersen } \\
\text { - 2008, p. 23, 31 } \\
\frac{\text { Pottish-Lewis, P. }}{\text {-2011, p. 12 }}\end{array}$ \\
\hline
\end{tabular}

${ }^{\star}$ Aligned with inputs from the Logic Model for Montessori Education (Culclasure, Daoust, Morris Cote, \& Zoll, 2019).

Note. Logic Model inputs of Credentialed Teachers, Larger Class Sizes, Continuing Professional Development, and Diverse Population of Students were not asked as Likert items in the Teacher Questionnaire. They were asked as direct questions about teacher and classroom characteristics in another section and will be included in future analysis. 


\section{References}

\section{Standards}

AMI/USA = Association Montessori International/USA. (2009). AMI/USA Montessori school standards. Alexandria, VA: AMI/USA

AMS = American Montessori Society . (2014). AMS school accreditation standards and criteria

MAFL = Montessori Australia Foundation Limited (2012). Montessori National Curriculum. The NAMTA Journal, 37(1).

NCMPS = National Center For Montessori in the Public Sector. (2015). Essential elements on Montessori practice in the public sector

MPPI = Montessori Public Policy Initiative. (2015). Montessori essentials.

Montessori and Others

Chattin-McNichols, J. (1992). The Montessori controversy. Albany, NY: Delmar.

Daoust, C. \& Suzuki, S. (2013). Montessori magnets and charters: Similarities and differences in implementation. Poster presented at the American Montessori Society annual conference, Orlando, FL.

Daoust, C. \& Suzuki, S. (2014). Public Montessori elementary: Three models of implementation. Poster presented at the American Montessori Society annual conference, Dallas, TX. Grazzini, B. K. (2010). The role of the disciplines for cosmic education. Communications 2010 Special Issue, pp. 84-93

Kahn, D. (1995). What is Montessori elementary? Cleveland: North American Montessori Teachers' Association

Lillard, A. S. (2005). Montessori: The science behind the genius. New York: Oxford University Press.

Lillard, P. P. (1996). Montessori today. New York: Schocken.

MacDonald, G. (2016). Becoming a scientific observer. The NAMTA Journal, (41)3, pp. 132-171

Montessori, M. (1963). Education for a new world. Madras, India: Kalakshetra

Montessori. M. (1964). The Montessori Method. New York: Schocken.

Montessori, M. (1965). Spontaneous activity in education: The advanced Montessori Method. Madras, India: Kalakshetra.

Montessori, M. (1970). The child in the family. New York: Avon.

Montessori, M. (1972). Education and peace (H. R. Lane, Trans.). Washington DC: Henry Regnery.

Montessori, M. (1973). To educate the human potential. Madras, India: Kalakshetra.

Montessori, M. (1976). From childhood to adolescence. New York: Schocken

Montessori, M. (1988). The discovery of the child. Oxford, England, Clio Press.

Montessori, M. (1989). The absorbent mind. New York, Dell.

Montessori. M. (1997a). Basic ideas of Montessori's educational theory: Extracts from Maria Montessori's writings and teachings. Oxford: ABC-Clio

Montessori. M. (1997b). The California lectures of Maria Montessori, 2015. Oxford: Clio.

Montessori, M. (2008). The child, society, and the world: Unpublished speeches and writings. Amsterdam, Netherlands: Montessori-Pierson

Montessori, M. (2013). The house of children: lecture, Kodaikanal, 1944 [Special issue]. The NAMTA Journal, (38)1, pp. 10-19.

Montessori. M. M. (1976). Education for human development. New York: Schocken.

North American Montessori Center. (2010, October 1). Re: The Montessori peace place: An important part of the classroom. [NAMC Montessori Teacher Training Blog]

Pendersen, H. \& Pendersen, J. (2008). What is Montessori? A basic guide to the principles, practices, and benefits of a Montessori education. San Anselmo, CA: Sandpiper Press Pottish-Lewis, P. (2011). Elementary classroom management: How to implement cosmic education. Rochester, NY: AMI/USA.

Rambusch, N. M. \& Stoops, J. A. (1992). The authentic American Montessori school: A guide to the self-study, evaluation, and accreditation of American schools committed to Montessori education. New York: AMS and the Commission on Elementary Schools of the Middle States Association.

Standing, E. M. (1957/1984). Maria Montessori: Her life and work. New York: New American Library. 